\title{
Daily Freeze-Thaw Cycles Affect the Transport of Metals in Streams Affected by Acid Drainage
}

\author{
Paula Guerra ${ }^{1,2}$, Kyle Simonson ${ }^{1}$, Christian González ${ }^{1}$, Jorge Gironás ${ }^{1,3,4}$, \\ Cristian Escauriaza 1,4, Gonzalo Pizarro ${ }^{1,3}$, Carlos Bonilla ${ }^{1,3}$ and Pablo Pasten 1,3,* \\ 1 Departamento de Ingeniería Hidráulica y Ambiental, Pontificia Universidad Católica de Chile, \\ Avenida Vicuña Mackenna 4860, Macul, 7820436, Santiago, Chile; paula.guerra@usm.cl (P.G.); \\ simonsonkylej@gmail.com (K.S.); crgonza1@uc.cl (C.G.); jgironas@ing.puc.cl (J.G.); \\ cescauri@ing.puc.cl (C.E.); gpizarro@ing.puc.cl (G.P.); cbonilla@ing.puc.cl (C.B.) \\ 2 Departamento de Ingeniería Química y Ambiental, Universidad Técnica Federico Santa María, \\ Avenida Vicuña Mackenna 3939, San Joaquín, 8940897, Santiago, Chile \\ 3 CEDEUS, Centro de Desarrollo Urbano Sustentable, El Comendador 1916, Providencia, 7520245, \\ Santiago, Chile \\ 4 CIGIDEN, Centro Nacional de Investigación para la Gestión Integrada de Desastres Naturales, \\ Vicuña Mackenna 4860, Macul, 7820436, Santiago, Chile \\ * Correspondence: ppasten@ing.puc.cl; Tel.: +56-2-2354-4227
}

Academic Editor: Athanasios Loukas

Received: 26 November 2015; Accepted: 14 February 2016; Published: 26 February 2016

\begin{abstract}
Stream flow rates with seasonal, daily, or hourly cycles due to freezing and thawing can control downstream chemical processes by changing the mixing ratio of reactive flows. The extent of these hydrologic-chemical interactions has not been fully realized yet. This work explored the link between daily freeze-thaw cycles and the fate and transport of metals at a model stream impacted by acid drainage. We characterized hydrological and physicochemical parameters at the confluence between the Caracarani River $(\mathrm{pH} \sim 8.6)$ and the Azufre River $(\mathrm{pH}<2)$, in northern Chile. Hourly water depth, temperature, and electrical conductivity monitoring coupled with $\mathrm{pH}$ and turbidity measurements revealed that maximum flow rates from thawing of the Azufre River induced characteristic daily drops in $\mathrm{pH}$ and turbidity. Shifts in $\mathrm{pH}$ controlled the precipitation and dissolution of arsenic-rich iron and aluminum reactive phases. Thus freeze-thaw processes are critical at streams receiving acid drainage where iron and aluminum phases form and are likely to impact the fate and transport of toxic metals in the system. This work highlights the importance of assessing the hydrological controls on flows and mixing ratios when studying the chemical reactivity and fate of contaminants at systems affected by acid drainage.
\end{abstract}

Keywords: diurnal cycles; aluminum; iron; arsenic; Lluta River; freeze-thaw; turbidity

\section{Introduction}

Water quality may be strongly affected by annual, seasonal, and daily periodicity in stream flow rate [1-5]. Changes in water quality can be caused by incoming waters that can dilute or concentrate chemical species [1-3,6-8] or incorporate sediments or nutrients into the rivers [1,9-11]. These processes can exert an important control in chemical speciation. Snow melting and freeze-thaw cycles are an example of processes that produce important changes in the flow rate and quality of surface waters. In terms of physical processes, freeze-up slows down or fully detains flow rate $[7,12]$. In terms of chemical processes, dissolved salts are displaced during the freezing process to the liquid phase. This is especially critical in systems affected by streams of acid drainage $(\mathrm{pH}<3)$. The melting of acid drainage produces trace metals, abrupt peaks in the concentration of anions $\left(\mathrm{SO}_{4}{ }^{-2}\right.$ and $\left.\mathrm{Cl}^{-}\right)$, and 
significant decreases in $\mathrm{pH}$ due to gradual melting and gradual mixing processes [3,7,13]. Additionally, acid drainage tends to occur near operating or abandoned mine sites at mountain ranges were freezing temperatures occur [14-16]. Periodic changes in flow due to snow melting and/or freezing-thawing at these sites are prone to occur, with consequential shifts in water quality and transport of toxic metals downstream.

When a surface stream receives a discharge of acid drainage, key geochemical and hydrologic interactions may occur. The fluvial domain where these interactions occur can be designated as a reactive confluence. Reactive confluences receiving acid drainage are known for chemical reactions that trigger the formation of iron and aluminum oxy/hydroxides and hydrosulfates. Examples of such sites are the Odiel River-Tintillo River in Spain $[17,18]$, Deer Creek-Snake River in the U.S. $[19,20]$ and the Cement Creek-Animas River in the U.S. [21,22]. Many studies have shown that iron and aluminum oxy/hydroxides play a fundamental role in the cycling of toxic elements including arsenic, copper, and zinc, among others [14,23-28]. The role reactive confluences play over the fate and transport of toxic elements has been studied from a geochemical perspective, along with the connection between hydrology and acid drainage $[29,30]$. However, the control daily freeze and thaw cycles have over the fate of contaminants at reactive confluences has not yet been fully realized. Daily freeze-thaw cycles may constitute an additional hydrologic control in the behavior of contaminants.

The objective of this work was to explore how daily variations in stream flowrates due to freeze-thaw cycles control the fate and transport of metals at confluences affected by acid drainage. The model system was the Azufre River-Caracarani River confluence in the Lluta River watershed, Northern Chile. Stream temperatures, flow rates, and electric conductivity (EC) were monitored at the Azufre River and Caracarani River. Turbidity and $\mathrm{pH}$ were measured as proxies for the concentration of reactive solids downstream from the confluence. This work shows how hydrologic and geochemical interactions can produce important variations in dynamics of contaminants within short temporal and spatial scales, with the potential impact at sites affected by acid drainage and extreme climatic conditions.

\section{Materials and Methods}

\subsection{Site of Study}

The Azufre River-Caracarani River confluence is located in the headwater of the upper Lluta River basin, Chile, with an area of $2305 \mathrm{~km}^{2}$ (Figure 1). The confluence is located at $17^{\circ} 50^{\prime} 21^{\prime \prime} \mathrm{S}$, $69^{\circ} 42^{\prime} 26^{\prime \prime} \mathrm{W}$ and at an elevation of $3986 \mathrm{~m}$. The Azufre River joins the Caracarani River, and from this point downstream it keeps the name of Caracarani River. The Azufre River ("Sulfur River" in English) originates at the Tacora Volcano, near an abandoned sulfur mine and tailings site. The oxidation of sulfur tailings and volcanic geothermal springs produce an acidic stream of high electric conductivity (or EC $\left.>9 \mathrm{mS} \cdot \mathrm{cm}^{-1}\right)$, low $\mathrm{pH}(\mathrm{pH}<2)$, and trace elements [15]. In contrast, the $\mathrm{pH}$ of the Caracarani River ranges between 8.2 and 8.6, alkalinity ranges between 20 and $232 \mathrm{mg} \cdot \mathrm{L}^{-1}$ of $\mathrm{CaCO}_{3}$, and EC values between 1.2 and $2.2 \mathrm{mS} \cdot \mathrm{cm}^{-1}$. The critical toxic element at this site is arsenic [15]. Water quality data for the Azufre River and Caracarani River are shown in Table 1.

The region of study has a high altitude plateau climate, with negligible precipitation between April and November and a wet season between December and March. As an example, Figure 2 shows the monthly rainfall measured between 2011 and 2012 in the region at an elevation of $3900 \mathrm{~m}$, with $484 \mathrm{~mm}$ of precipitation (rain) between November and April. Below zero ambient temperatures occur due to the high altitude and closeness to the Andes [31] and can reach down to $-10{ }^{\circ} \mathrm{C}$ or lower from May to September, as indicated in Figure 2. High flow rates are driven by increased rainfall during the Bolivian winter, whereas much lower flow rates take place between April and November, as reported in other studies [32-34] and reflected in our records from 2010 to 2011 (Figure 3).

The Azufre River-Caracarani River confluence is a remote site. It is located $2200 \mathrm{~km}$ from Santiago (Chile's capital) and $140 \mathrm{~km}$ from Arica (the closest main city). Due to the remoteness of the 
location, extreme weather conditions, and safety protocols, manual sampling and operator-dependent measurements were taken only during the daytime (9 a.m.-5 p.m.). Such constraints did not compromise pursuing the objectives of the study. Continuous measurements of flowrate, temperature, and electric conductivity were performed with data-logging sensors deployed in situ (described below).

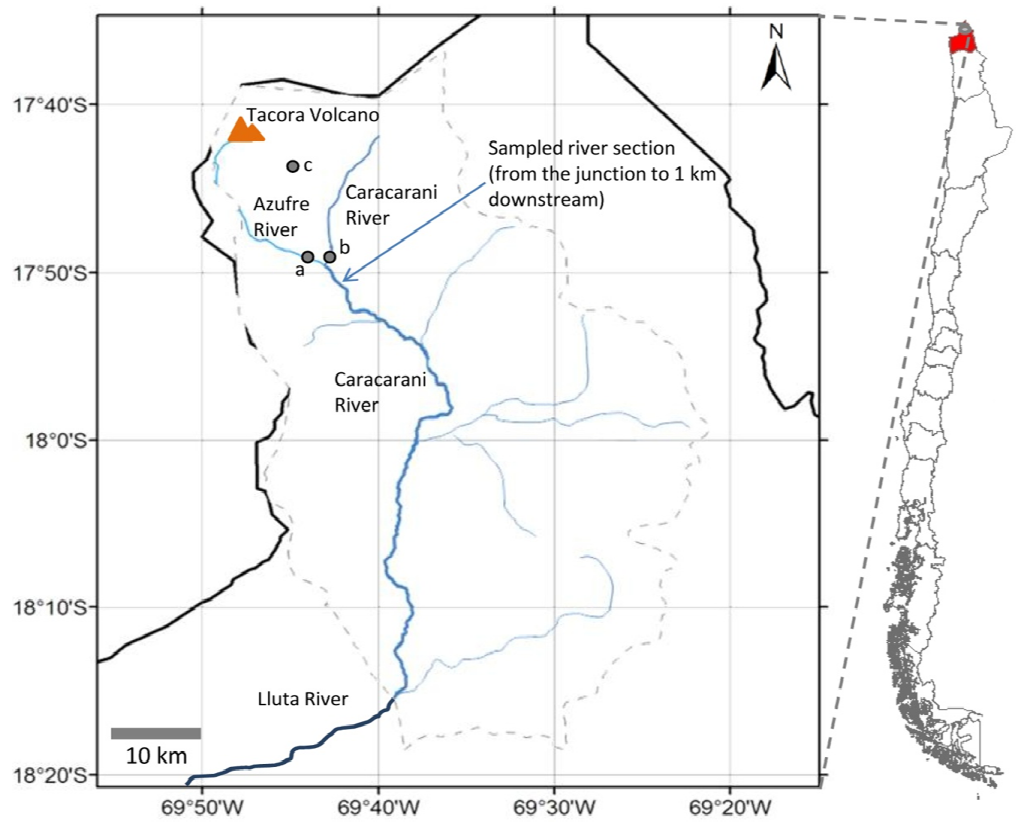

Figure 1. Site of study. The Azufre River joins the Caracarani River in the higher Lluta River basin, northern Chile. The Lluta River is born when the Caracarani River joins the Colpitas River. Points "a" and " $\mathrm{b}$ " indicate where stream flow, temperature, EC, turbidity, and $\mathrm{pH}$ were measured. The arrow shows the stream segment along which turbidity, EC, and $\mathrm{pH}$ were measured downstream of the junction point. Point " $\mathrm{c}$ " indicates the location of the meteorological station.

(a)

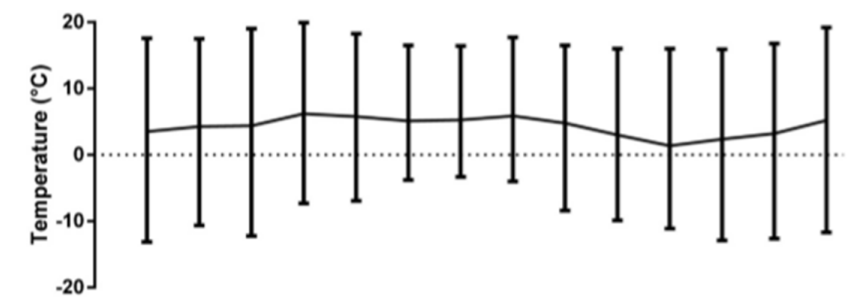

(b)

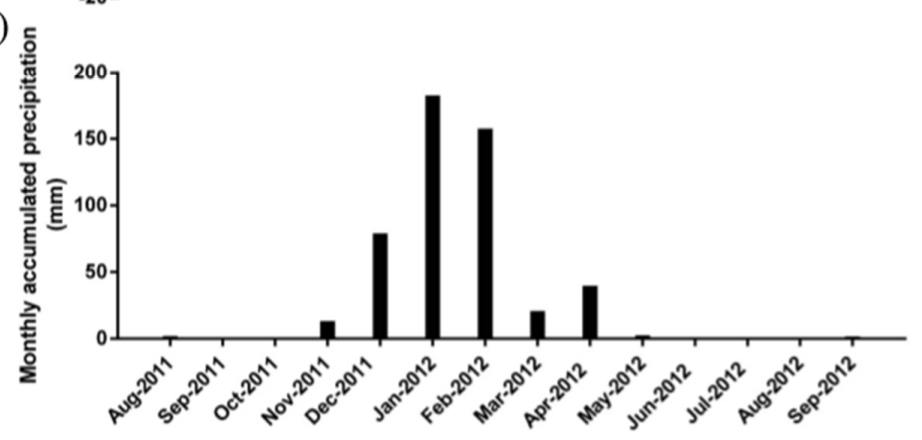

Figure 2. Temperature data (a) and monthly accumulated precipitation (b) recorded within $8.5 \mathrm{~km}$ of the site of study (point " $c$ " in Figure 1). In (a), the continuous horizontal line depicts monthly mean values while the vertical lines indicate minimum and maximum values within the month. 
Table 1. Representative water quality data for the Azufre River and Caracarani River (sampling period: 2010-2012).

\begin{tabular}{|c|c|c|c|}
\hline Parameter & Unit & Azufre River & Caracarani River \\
\hline $\mathrm{pH}$ & - & $\begin{array}{c}1.91^{(\mathrm{a})}(11)^{(\mathrm{b})} \\
(1.0-2.2)^{(\mathrm{c})}\end{array}$ & \\
\hline Alkalinity & $\mathrm{mg} \mathrm{CaCO}{ }_{3} \cdot \mathrm{L}^{-1}$ & - & $\begin{array}{c}110(5) \\
20-232.3\end{array}$ \\
\hline $\mathrm{SO}_{4}^{-2}$ & $\mathrm{mg} \cdot \mathrm{L}^{-1}$ & $\begin{array}{c}3370.4(8) \\
(1556-5210)\end{array}$ & $\begin{array}{l}408.5(8) \\
(217-571)\end{array}$ \\
\hline $\mathrm{Cl}^{-}$ & $\mathrm{mg} \cdot \mathrm{L}^{-1}$ & $\begin{array}{c}1319.6(8) \\
(530-1927)\end{array}$ & $\begin{array}{c}154.7(8) \\
(85.8-367)\end{array}$ \\
\hline $\mathrm{Na}^{+}$ & $\mathrm{mg} \cdot \mathrm{L}^{-1}$ & $\begin{array}{c}334.4(5) \\
(209.3-659)\end{array}$ & $\begin{array}{c}200(5) \\
128.9-218.7\end{array}$ \\
\hline $\mathrm{K}^{+}$ & $\mathrm{mg} \cdot \mathrm{L}^{-1}$ & $\begin{array}{c}87.7(5) \\
(58.9-162)\end{array}$ & $\begin{array}{c}26.72(5) \\
(14.7-28.8)\end{array}$ \\
\hline $\mathrm{Ca}^{+2}$ & $\mathrm{mg} \cdot \mathrm{L}^{-1}$ & $\begin{array}{c}244.5(5) \\
(203.9-296.8)\end{array}$ & $\begin{array}{c}96.2(5) \\
(76.01-115.3)\end{array}$ \\
\hline $\mathrm{Mg}^{+2}$ & $\mathrm{mg} \cdot \mathrm{L}^{-1}$ & $\begin{array}{c}159.2(5) \\
(100-230)\end{array}$ & $\begin{array}{c}62.7(5) \\
(38.2-68)\end{array}$ \\
\hline Total Fe & $\mathrm{mg} \cdot \mathrm{L}^{-1}$ & $\begin{array}{c}59.1(7) \\
(35.3-83.1)\end{array}$ & $\begin{array}{c}0.86(6) \\
(0.3-3.6)\end{array}$ \\
\hline Dissolved Fe $(<0.45 \mu \mathrm{m})$ & $\mathrm{mg} \cdot \mathrm{L}^{-1}$ & $\begin{array}{c}59.1(6) \\
(32-85.5)\end{array}$ & $\begin{array}{c}0.82(5) \\
(0.39-1.3)\end{array}$ \\
\hline Total Al & $\mathrm{mg} \cdot \mathrm{L}^{-1}$ & $\begin{array}{c}142.9(5) \\
(97.1-156.9)\end{array}$ & $\begin{array}{c}0.03(3) \\
(0.02-0.7)\end{array}$ \\
\hline Dissolved Al $(<0.45 \mu \mathrm{m})$ & $\mathrm{mg} \cdot \mathrm{L}^{-1}$ & $\begin{array}{c}142.9(3) \\
(70.1-156.9)\end{array}$ & $\begin{array}{c}0.02(3) \\
(0.01-0.7)\end{array}$ \\
\hline Total As & $\mathrm{mg} \cdot \mathrm{L}^{-1}$ & $\begin{array}{c}1.78(7) \\
(1.05-2.6)\end{array}$ & $\begin{array}{c}0.09(6) \\
(0.03-0.13)\end{array}$ \\
\hline Total B & $\mathrm{mg} \cdot \mathrm{L}^{-1}$ & $\begin{array}{c}18.2(4) \\
(12.8-19.4)\end{array}$ & $\begin{array}{c}2.7(2) \\
(2.5-2.9)\end{array}$ \\
\hline Total Zn & $\mathrm{mg} \cdot \mathrm{L}^{-1}$ & $\begin{array}{c}9.8(7) \\
(6.3-12.6)\end{array}$ & $\begin{array}{c}0.25(5) \\
(0.09-0.97)\end{array}$ \\
\hline
\end{tabular}

(a) Average; $^{(b)}$ Number of measurements; ${ }^{(c)}$ Measurement range (minimum and maximum value measured).

(a)

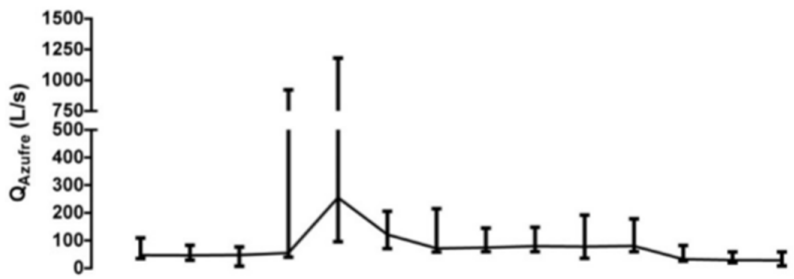

(b)

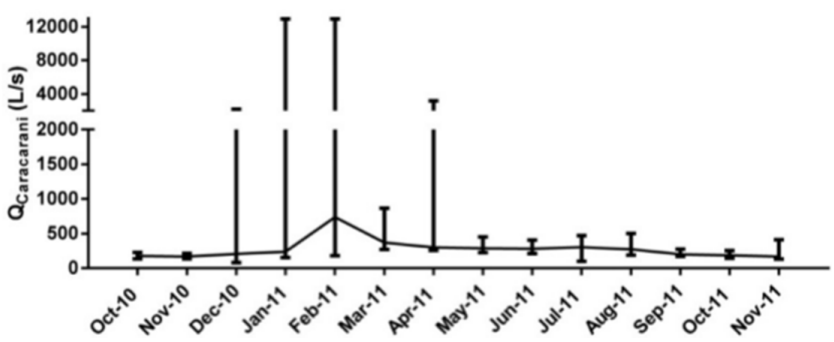

Figure 3. Mean monthly flow rate data for the Azufre River (a) and Caracarani River (b), measured during 2010-2011. The continuous horizontal line depicts mean values while the vertical lines indicate minimum and maximum daily flow rates. 


\subsection{Hydrologic Measurements}

The rainfall and ambient temperature were recorded every $15 \mathrm{~min}$ by the meteorological station located $8.5 \mathrm{~km}$ from the confluence at an elevation of approximately $3900 \mathrm{~m}$ (Figure 1). The station was equipped with a data logger (Em50 Data Logger, Decagon Devices, Pullman, WA, USA) connected to a temperature sensor (ECH2O sensor, Decagon Devices, Pullman, WA, USA) and a rain gauge (ECRN-50, Decagon Devices, Pullman, WA, USA).

Water pressure, water temperature, and EC were recorded hourly at the Azufre River and Caracarani River using a data logger (Aqua TROLL 200 Data Logger, InSitu Inc., Bingen, WA, USA). The data presented corresponded to records from January to November 2011. The sensors were installed $700 \mathrm{~m}$ upstream of the confluence at the Azufre River and $100 \mathrm{~m}$ upstream at the Caracarani River (points a and b in Figure 1, respectively). Conductivity sensors were calibrated with a $\mathrm{KCl}$ solution $0.01 \mathrm{M}$ and $1.41 \mathrm{mS} \cdot \mathrm{cm}^{-1}$ at the Caracarani River, and a $\mathrm{KCl}$ solution $0.1 \mathrm{M}$ and $12.8 \mathrm{mS} \cdot \mathrm{cm}^{-1}$ at the Azufre River through several field campaigns. Water pressure values in both rivers were corrected using atmospheric pressure values recorded with a barometric sensor (Baro Troll Data Logger, InSitu Inc., Bingen, WA, USA) and utilized to further calculate water depth and estimate stream flow rates through rating curves [35]. These curves were computed after several field campaigns between September 2010 and March 2013, which allowed for obtaining eight points of the rating curve for the Azufre River and four points for the Caracarani River. Stream flow velocity (ms ${ }^{-1}$ ) and cross section area $\left(\mathrm{m}^{2}\right)$ were measured using a handheld acoustic Doppler velocimeter (Flowtracker Handheld ADV, Sontek, San Diego, CA, USA) equipped with an interface to estimate stream flow rate $\left(\mathrm{m}^{3} \cdot \mathrm{s}^{-1}\right)$. Finally, analytical expressions were fitted to these curves in order to automate the estimation of the flow rates from the measured water levels.

\subsection{Hydrochemical Measurements and Sampling}

Turbidity and $\mathrm{pH}$ were measured hourly from 9 a.m. to 5 p.m. during a field campaign in August 2012 at points $a$ and $b$ and at the stream segment downstream of the confluence indicated in Figure 1 (from the confluence to $1 \mathrm{~km}$ downstream). Downstream measurements were done at 90, 180, 320, and $1000 \mathrm{~m}$ from the junction. A Portable Turbidity Meter (HI 98713, Hanna Instruments, USA) was used and calibrated daily with standardized solutions (0.1 NTU, 1 NTU, 10 NTU, and $100 \mathrm{NTU}$ ). The pH and conductivity were measured with a multi-parameter probe (Hach HQ40d portable meter, Hach Company, Loveland, CO, USA). The calibration of the $\mathrm{pH}$ sensor was performed using buffer solutions of $\mathrm{pH} 4,7$, and 10 (Hach Company, Loveland, CO, USA). Correct functioning of the $\mathrm{pH}$ electrode at $\mathrm{pH}<4$ were corroborated by plotting $\mathrm{pH}$ measurements against potential measurements $(\mathrm{mV})$ as done by Nordstrom et al. [36].

Turbidity was selected as an in situ proxy measurement for particle formation [37,38]. Field measurements at the site between 2008 and 2012 showed that the concentration of suspended solids larger than $0.45 \mu \mathrm{m}$ ( $y$ value) ranged between 1 and $43 \mathrm{mg} \cdot \mathrm{L}^{-1}$, and were significantly correlated with turbidity ( $x$ value) through a mathematical regression of $y=0.71 x-0.56$ (coefficient of determination $R^{2}=0.72$, with a level of significance of $\alpha=5 \%$ according to a standard normal distribution two-tailed statistical test) [39].

Suspended solids were sampled through several field campaigns (see Table 2). These were collected by using a portable barrel filter of 2 L capacity (Barrel Filter Holder, Geotech Environmental Equipment Inc., Denver, CO, USA). Suspended solids were retained onto pre-weighed cellulose acetate membranes ( $>0.45 \mu \mathrm{m}$ from the same company). Aqueous samples (non-filtered samples) were collected in the field, then filtered and stored at $4{ }^{\circ} \mathrm{C}$ when conditions allowed. 
Table 2. Concentration of total suspended solids (TSS) and corresponding concentrations of arsenic (As), iron (Fe), and aluminum (Al). Samples were taken randomly, downstream from the confluence, through several field campaigns.

\begin{tabular}{ccccc}
\hline $\mathbf{p H}$ & TSS, $\mathbf{~ m g} / \mathbf{L}$ & As, $\mathbf{~} \mathbf{g} / \mathbf{k g}$ & $\mathbf{F e}, \mathbf{g} / \mathbf{k g}$ & $\mathbf{A l}, \mathbf{g} / \mathbf{k g}$ \\
\hline 3.51 & 14.2 & 3950 & 71.5 & N.A \\
3.81 & 8.6 & 8700 & 150.3 & 25.3 \\
4.49 & 7.55 & 1848 & 51.8 & 14 \\
4.58 & 50.35 & 1264 & 38.2 & 34.9 \\
5.92 & 80.8 & 1635 & 33.4 & 76.5 \\
6.46 & 40.5 & 1688 & 35.7 & 62.7 \\
\hline
\end{tabular}

N.A: Information not available.

\subsection{Analytical Methods}

Membranes containing suspended solids were dried at $40{ }^{\circ} \mathrm{C}$ for $24 \mathrm{~h}$ and then placed inside Teflon tubes along with $12 \mathrm{~mL}$ of aqua regia $\left(\mathrm{HCl}\right.$ and $\left.\mathrm{HNO}_{3}\right)$ for microwave digestion (Mars Microwave System, MarsXpress-5, CEM Corporation, Matthews, NC, USA), according to the EPA protocol number 3015A [40]. Blank membranes were also digested for quality control.

Digested aqueous and solid field samples were analyzed for iron, aluminum, and arsenic through Inductively Coupled Plasma-Optical Emission Spectrometry (ICP-OES, Optima 7300 V, Perkin Elmer, USA).

\section{Results and Discussion}

\subsection{Diurnal Cycles in Stream Flow Rates, Temperature, and Electric Conductivity}

The flow rates of the Azufre River $\left(Q_{\text {Azufre }}\right)$ and Caracarani River $\left(Q_{\text {Caracarani }}\right)$ showed daily cycles, as illustrated in Figure 4, where flow rates measured in August 2011 are shown (additional data is presented in the Supplementary Materials). The periodicity of the time series was identified visually and by means of the autocorrelation function, which determines how the variable $x$ measured at time $t$ correlates with the measured value at time $t-k$, where $k=1,2, \ldots n$ is the so called "lag-time" [40]. This test was performed using the Signal Processing Toolbox of Matlab. A strong $24 \mathrm{~h}$ periodicity for $Q_{A z u f r e}$ and $Q_{\text {Caracarani }}$ was found, as well as for the temperature and the EC of the Azufre River ( $T_{\text {Azufre }}$ and $E C_{A z u f r e}$, respectively). As a consequence, the proportion of $Q_{\text {Azufre, }}$ defined as $\left.\mathrm{Q}_{\text {Azufre }} /\left(\mathrm{Q}_{\text {Azufre }}+\mathrm{Q}_{\text {Caracarani }}\right)\right)$, exhibited the same periodicity.

Daily cycles experienced by $Q_{\text {Azufre }}$ were attributed to the freezing and thawing of the stream. The Azufre River typically remains at $0{ }^{\circ} \mathrm{C}$ from 9 p.m. to 10 a.m. the next morning when the ambient temperatures are negative and can reach down to $-13^{\circ} \mathrm{C}$ during the colder months (Figure 2). The partial freezing of the Azufre River upstream causes the stream flow rate to drop while the water temperature remains at $0{ }^{\circ} \mathrm{C}$. Once the temperature passes the $0{ }^{\circ} \mathrm{C}$ threshold, the melting causes a sudden peak of $Q_{\text {Azufre }}$. This process occurred on a daily basis while the ambient temperature was low enough for the stream to remain partially frozen (Figure 4). $\mathrm{EC}_{\text {Azufre }}$ also exhibited cyclic behavior. This process does not occur between December and April, when stream freezing does not take place and rainfall drives stream flows (see Supplementary Materials).

A temporal cross-correlation analysis (i.e., a lagged correlation analysis between two time series shifted in time relative to one another) [41] was used to detect the correlation between $Q_{\text {Azufre }}$ and $\mathrm{T}_{\text {Azufre }}$ data, and between $\mathrm{T}_{\text {Azufre }}$ and $\mathrm{EC}_{\text {Azufre }}$ data, which also experience cyclic behavior (data based on the whole 2010-2011 record). Results show that $\mathrm{T}_{\text {Azufre }}$ and $\mathrm{Q}_{\text {Azufre }}$ correlated $(r=0.38)$ with a lag time of $7 \mathrm{~h}$, (i.e., $\mathrm{Q}_{\text {Azufre }}$ reaches its maximum value around $7 \mathrm{~h}$ after $\mathrm{T}_{\mathrm{Azufre}}$ reaches its maximum value, see Figure 5). Similarly, a cross correlation was observed between $\mathrm{T}_{\text {Azufre }}$ and $\mathrm{EC}_{\text {Azufre }}(r=-0.63)$ with a lag time of $1 \mathrm{~h}$ (i.e., $\mathrm{EC}_{\text {Azufre }}$ reached its minimum value around $1 \mathrm{~h}$ after after $\mathrm{T}_{\text {Azufre }}$ reaches 
its minimum value). Note that higher values of $r$ were not reached because the water temperature is constrained in the low range to $0{ }^{\circ} \mathrm{C}$, and thus the variability of $\mathrm{T}_{\text {Azufre }}$ is more limited than that of $\mathrm{Q}_{\text {Azufre }}$ and $\mathrm{EC}_{\text {Azufre }}$. However, a standard normal distribution two-tailed statistical test indicated both cross-correlations were statistically significant for a level of significance of $\alpha=5 \%$. Overall, the temporal crossed correlations between these variables further demonstrate that $Q_{\text {Azufre }}$ was controlled by the freeze-thaw cycles.

(a)

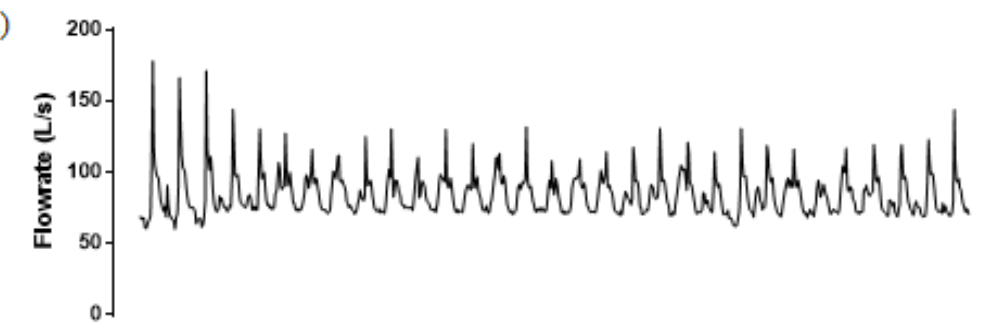

(b)

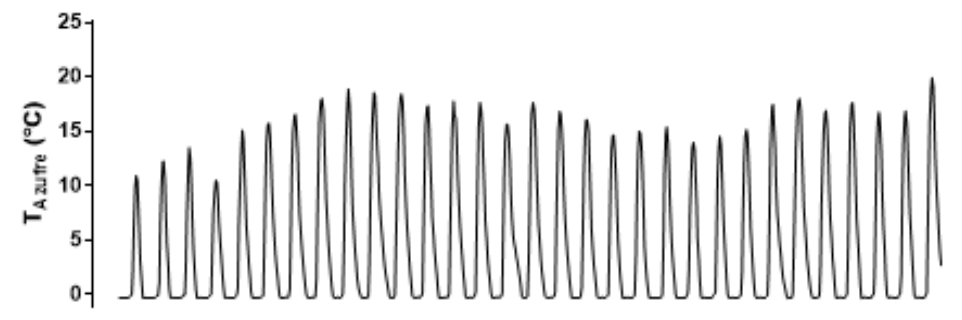

(c)

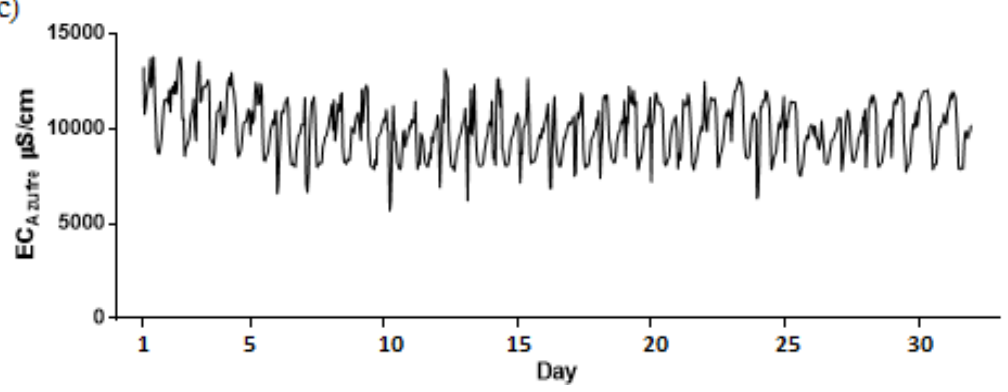

Figure 4. Hourly stream flow rates, temperatures and EC registered upstream of the confluence in August 2011. (a) $\mathrm{Q}_{\text {Azufre; }}$ (b) $\mathrm{T}_{\text {Azufre; }}$ and (c) $\mathrm{EC}_{\text {Azufre }}$ data. Autocorrelation analysis showed a $24 \mathrm{~h}$ periodicity for $\mathrm{Q}_{\text {Caracarani }}, \mathrm{Q}_{\text {Azufre, }} \mathrm{T}_{\text {Azufre, }}$ and $\mathrm{EC}_{\text {Azufre }}$. The x-axis depicts the day of the month.

The partial freezing of the Caracarani River upstream of the confluence occurs to a lesser extent than for the Azufre River (see Figures 4 and 5). Maximum QCaracarani values occur between noon and 3 p.m., when the temperature of the Caracarani River ( $\mathrm{T}_{\text {Caracarani }}$ ) was also at a maximum. These cyclic variations also affect the water quality downstream from the confluence, as the supply of acidity from the Azufre River is counterbalanced by the alkalinity of the Caracarani River (QCaracarani is 2 to 12 times higher than $\left.\mathrm{Q}_{\text {Azufre }}\right)$.

Maximum stream flowrates at both streams occurred within distinct times of the day. Indeed, $65 \%$ of minimum total flow rates in both the Azufre and Caracarani River occurred between midnight and 9 a.m., when both rivers tended to remain partially frozen according to temperature measurements (remained at $0^{\circ} \mathrm{C}$ ). Seventy-two percent of maximum $\mathrm{Q}_{\text {Azufre }}$ values occurred between 8 a.m. and noon, when the temperature of the Azufre River passed the $0{ }^{\circ} \mathrm{C}$ threshold. These variations were coincident with the mixing proportion between the streams $\left(Q_{\text {Azufre }} /\left(Q_{\text {Azufre }}+Q_{\text {Caracarani }}\right)\right)(72 \%$ of maximum $\mathrm{Q}_{\text {Azufre }} /\left(\mathrm{Q}_{\text {Azufre }}+\mathrm{Q}_{\text {Caracarani }}\right)$ values occurred between 8 a.m. and noon). Finally, maximum flow rates in the Caracarani River, as 77\% of maximum QCaracarani values occurred between noon and 4 p.m. 
Variations in the time $\mathrm{Q}_{\text {Caracarani }}$ reached its maximum might be explained by freezing-melting cycles occurring near its origin, with delayed effects due to the distance to the confluence. Maximum values of $Q_{\text {Caracarani }} /\left(Q_{\text {Azufre }}+Q_{\text {Caracarani }}\right)$, however, were widely spread (63\% of these values occurred between noon and midnight). This was due to decreased flow rates towards the evening.

(a)

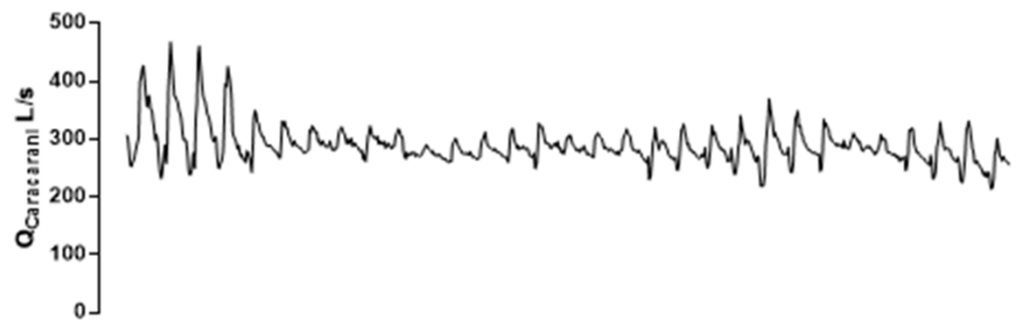

(b)

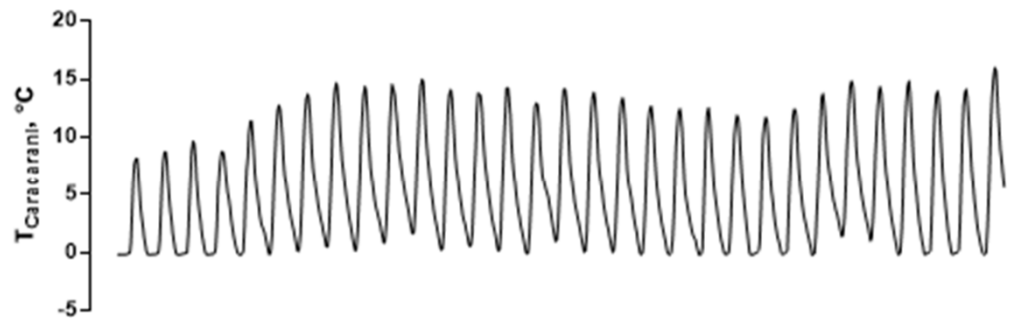

(c)

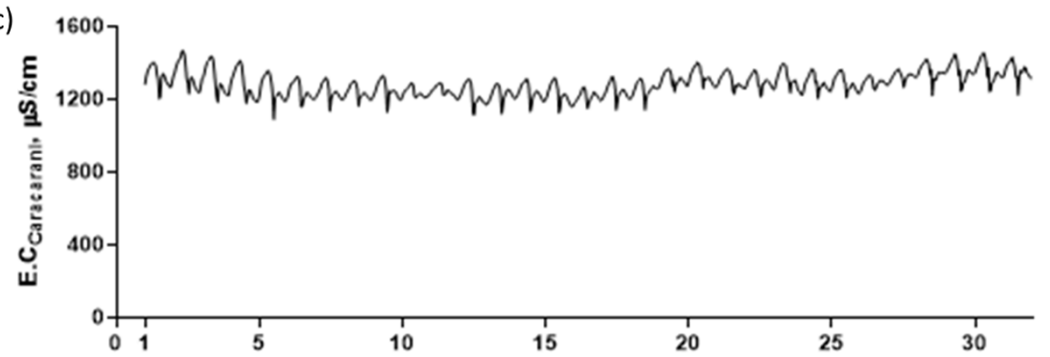

Figure 5. Hourly data of the Caracarani River from August 2011. QCaracarani (a); $\mathrm{T}_{\text {Caracarani }}(\mathbf{b})$; and $\mathrm{EC}_{\text {Caracarani }}(\mathbf{c})$. The axis depicts the days of the month.

\subsection{Diurnal Cycles in Particle Formation Downstream from the Confluence}

Diurnal cycles in the formation of suspended solids (detected as changes in turbidity) were also detected downstream from the confluence. Characteristic peaks and drops in turbidity and $\mathrm{pH}$ were observed within specific time frames (Figure 6). Global turbidity and $\mathrm{pH}$ peaks were consistently observed early in the morning. For example, temporal measurements taken on 20 August at $320 \mathrm{~m}$ downstream from the confluence showed a characteristic global turbidity and $\mathrm{pH}$ peaks early in the morning (reaching up to $45 \mathrm{NTU}$ at $\mathrm{pH}$ 5.2); these peaks were not as clear in the other time series as measurements taken later in the morning. A sudden turbidity and $\mathrm{pH}$ drop was consistently observed between 9 and 11 a.m. at all post-confluence sampling points. Another turbidity and $\mathrm{pH}$ peak occurred in the afternoon (between noon and 2 p.m.). The consistent peaks in these parameters indicate hourly water quality changes, consistent with the hourly hydrologic changes, as observed in Figure 7. Minimum values of $\mathrm{pH}$ and turbidity occurring within the same period maximum values of $\mathrm{Q}_{\text {Azufre }} /\left(\mathrm{Q}_{\text {Azufre }}+\mathrm{Q}_{\text {Caracarani }}\right)$ were observed. Local peaks in turbidity and $\mathrm{pH}$ occurring within the same period values of maximum $Q_{\text {Caracarani }}$ were observed. 
(a)
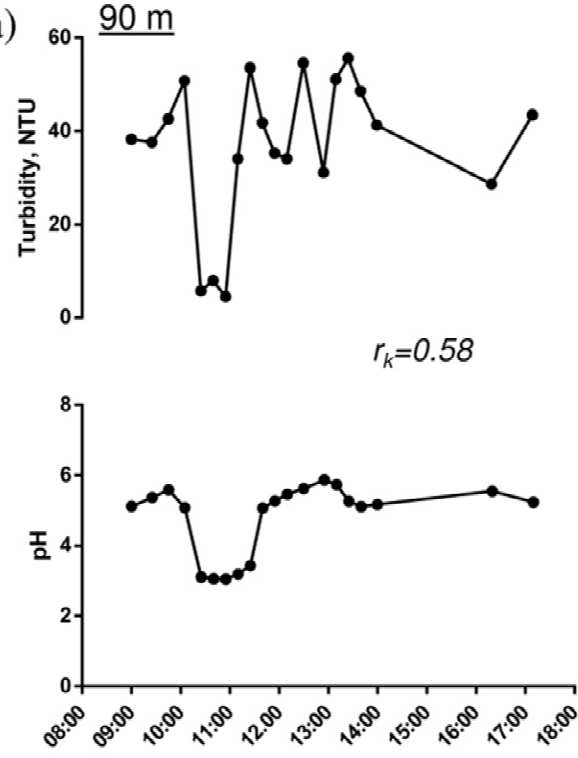

(c)

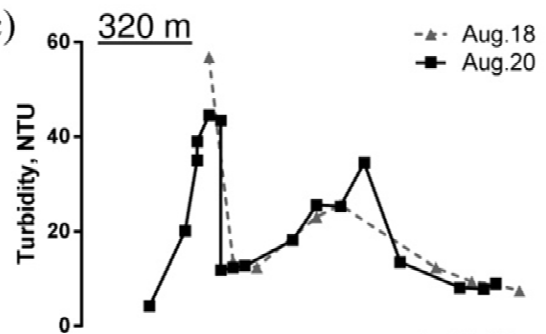

$r_{k}=0.65$ (Aug. 18

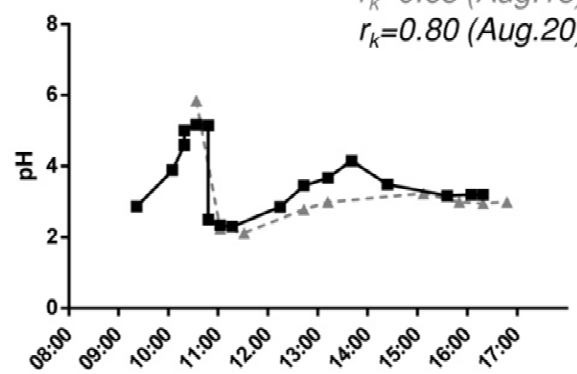

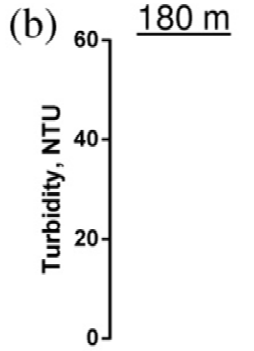

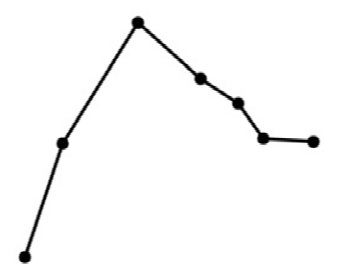

$r_{k}=0.95$

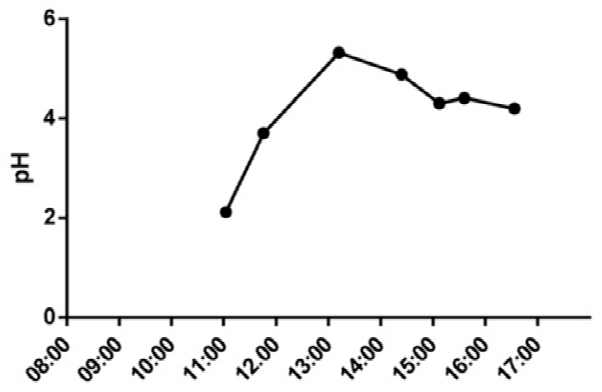

(d)
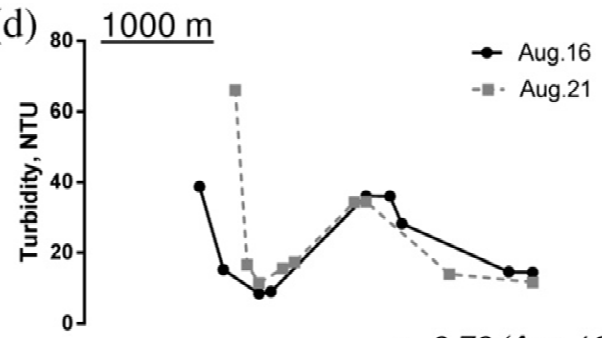

$r_{k}=0.76$ (Aug.16)

$r_{k}=0.87$ (Aug. 21)

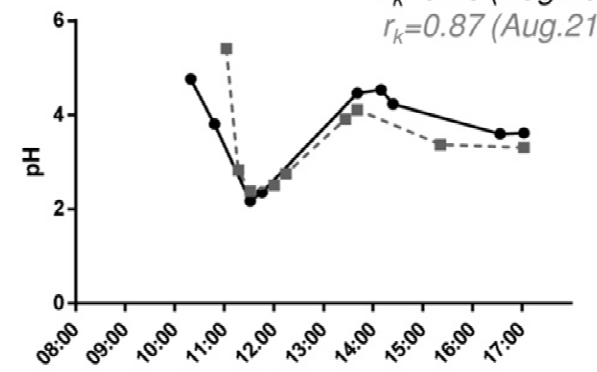

Figure 6. Turbidity and $\mathrm{pH}$ time series. Measurements were taken at 90 (a); 180 (b); 320 (c); and $1000 \mathrm{~m}$ (d) downstream from the confluence. A global peak (before 11 a.m.), a characteristic sink in the morning (between 11 a.m. and 12 p.m.), and a local peak towards the afternoon (between 1 and 2 p.m.) were observed. Turbidity and $\mathrm{pH}$ were highly correlated (correlation coefficients $\mathrm{r}_{\mathrm{k}}$ values are shown in each panel).

A high correspondence between turbidity and $\mathrm{pH}$ was identified downstream from the confluence. This dependence was determined by $\mathrm{pH}$ controlled by incoming inflow ratios $\left(Q_{\text {Azufre }} /\left(Q_{\text {Caracarani }}+Q_{\text {Azufre }}\right)\right)$, which caused the precipitation of mineral phases attributable to iron and aluminum oxides. Simultaneous measurements of $\mathrm{pH}$ and turbidity were significantly correlated, with correlation coefficients $\left(\mathrm{r}_{\mathrm{k}}\right)$ that ranged between 0.58 and 0.95 (see Figure 7). Additionally, turbidity versus $\mathrm{pH}$ showed a positive linear regression from $\mathrm{pH} 2$ to approximately 5 , as seen in Figure 8 . Turbidity (suspended solids) was controlled by the precipitation of iron and aluminum phases, which are $\mathrm{pH}$-controlled chemical reactions. Evidence of this is the presence of suspended solids, collected in the field, which showed high concentrations of iron and aluminum (Table 2). Furthermore, we developed a preliminary geochemical model that considered the formation of amorphous iron hydroxide $\left(\mathrm{Fe}(\mathrm{OH})_{3}(\mathrm{a})\right)$ and amorphous aluminum hydroxide $\left(\mathrm{Al}(\mathrm{OH})_{3}(\mathrm{a})\right)$ at different mixing ratios 
between the Azufre River and Caracarani River (see Supplementary Materials). This simplified model showed that $\mathrm{Fe}(\mathrm{OH})_{3}$ was feasible at $\mathrm{pH}>3$, while $\mathrm{Al}(\mathrm{OH})_{3}$ was feasible at $\mathrm{pH}>5$. It is also known that in natural systems $\mathrm{Fe}(\mathrm{OH})_{3}(\mathrm{a})$ becomes saturated at $\mathrm{pH}>3$ and that aluminum hydroxide precipitates at $\mathrm{pH}>4.5$ [42]. Although there are other iron and aluminum phases involved (such as hydrosulfates [43]), the analysis is consistent with how turbidity simultaneously increases with $\mathrm{pH}$. These increases in turbidity downstream are not caused by incoming of suspended solids from upstream of the confluence. The turbidity measured at the Azufre River and Caracarani River fluctuated between 2 and 14 NTU, respectively. One hundred percent of turbidity values measured downstream were higher than 4 NTU (69\% were higher than 14 NTU), indicating that turbidity increases were mainly due to $\mathrm{pH}$-dependent chemical reactions.

(a)
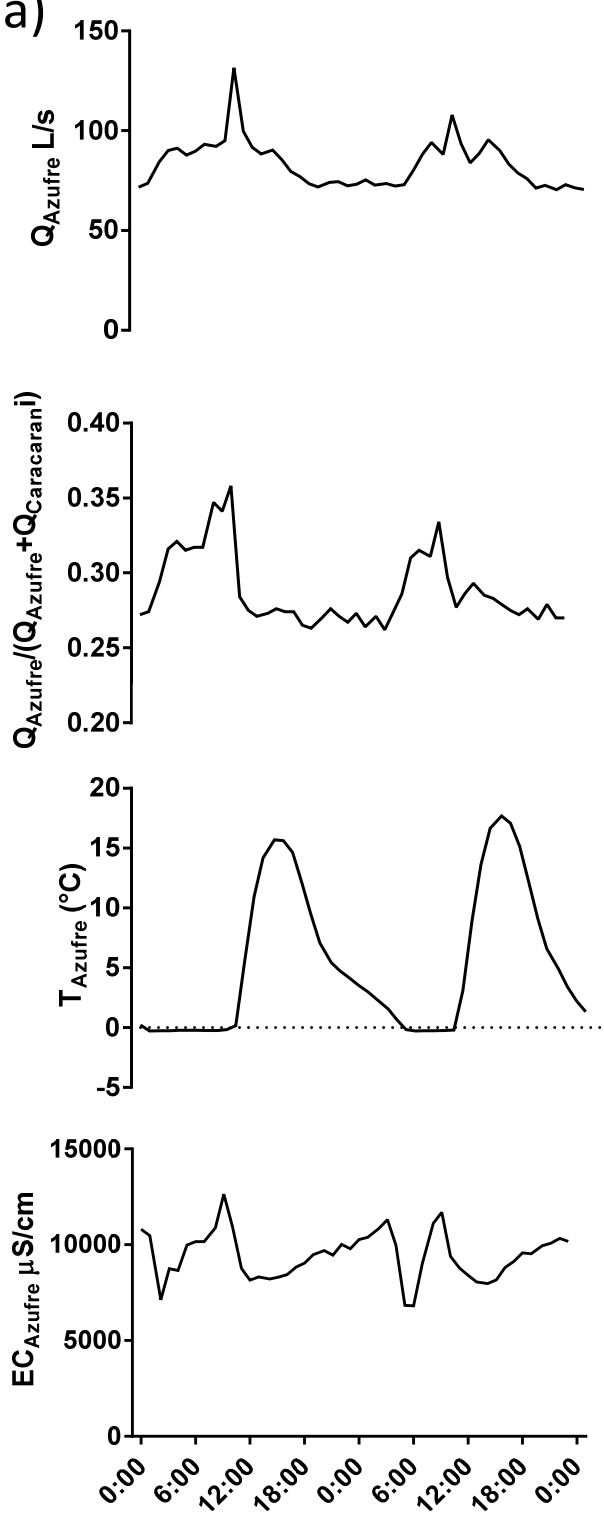

(b)
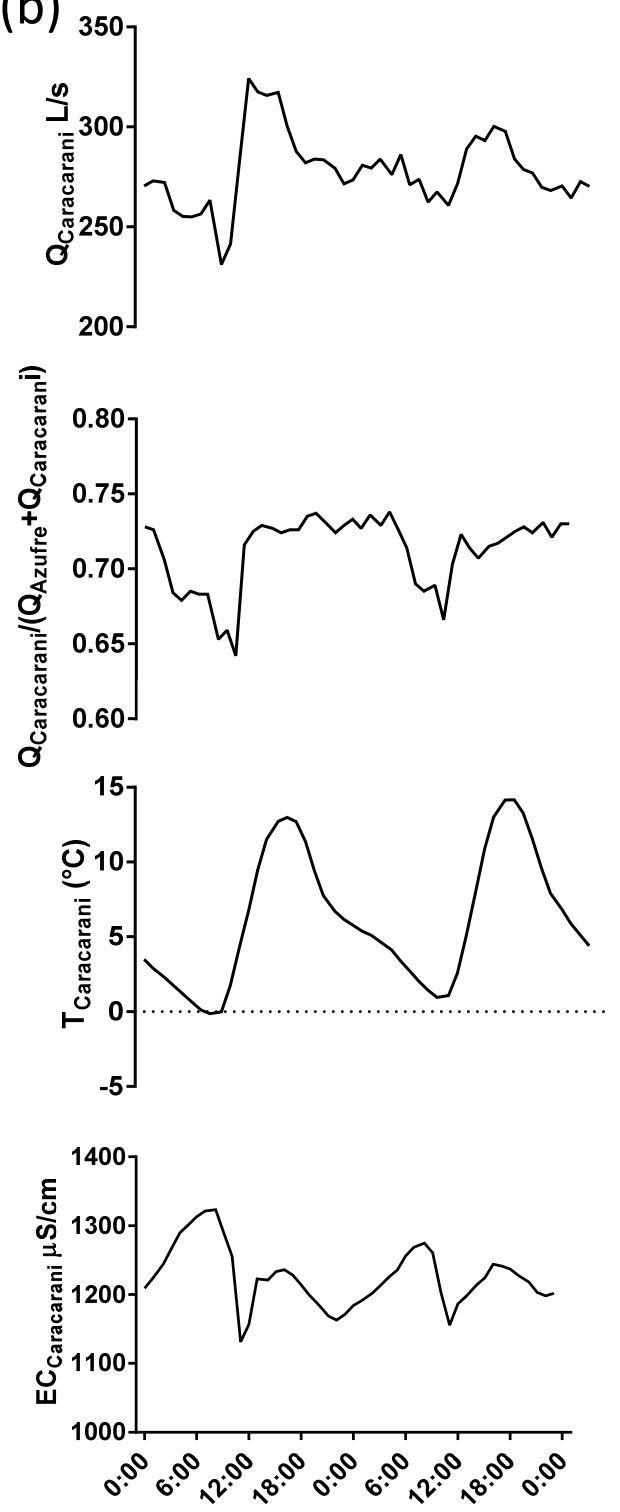

Figure 7. Representative daily cycles of the streams for 15-16 August 2011: Azufre River data (a); and Caracarani River data (b). The peaks in $Q_{\text {Azufre }}$ occurred when the $\mathrm{T}_{\text {Azufre }}$ exceeded $0{ }^{\circ} \mathrm{C}$ with an approximate lag of $7 \mathrm{~h}$. Q $\mathrm{Q}_{\text {Azufre }}$ peaks occurred at the same time peaks in mixing ratio $\left(Q_{\text {Azufre }} /\left(Q_{\text {Azufre }}+Q_{\text {Caracarani }}\right)\right)$ While the Azufre River remained partially frozen, EC tended to reach higher values with an approximate lag of $1 \mathrm{~h}$. Q Caracarani reached peak values towards the mid-afternoon. 


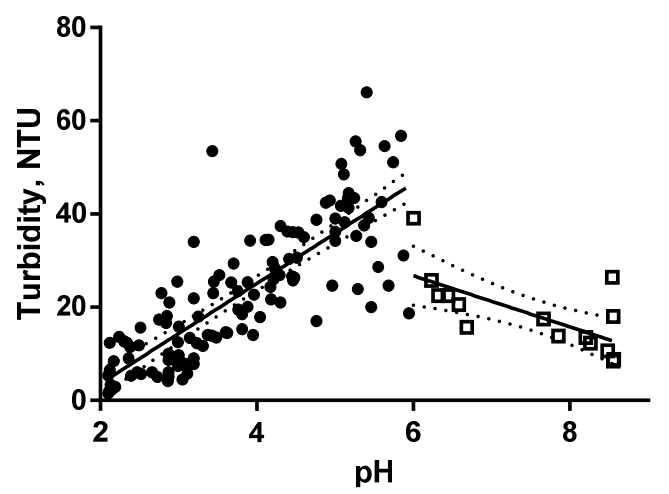

Figure 8. Turbidity versus $\mathrm{pH}$ shows a positive linear regression from $\mathrm{pH} 2$ to 5.5 (circles), and decreased from $\mathrm{pH} 5.5$ and upward (squares). The increase in turbidity was attributable to iron and aluminum phases that form within $\mathrm{pH} 3-5$.

The peaks of $\mathrm{pH}$ occurring before noon can be attributed to lower total flow rates, which triggered higher turbidity values (no particular patterns in $\mathrm{Q}_{\text {Azufre }} /\left(\mathrm{Q}_{\text {Azufre }}+\mathrm{Q}_{\text {Caracarani }}\right)$ were found). Additionally, lower flowrates (higher residence times [44,45]), caused increases in turbidity. The subsequent drop in $\mathrm{pH}$ observed between 9 a.m. and noon (Figure 7) was caused by peaks in $\mathrm{Q}_{\text {Azufre }} /\left(\mathrm{Q}_{\text {Azufre }}+\mathrm{Q}_{\text {Caracarani }}\right)$ (Figures 4 and 6), thus diminishing turbidity. Diminished suspended solids can be attributed to dissolved precipitates. Finally, the local peak in $\mathrm{pH}$ observed in the afternoon (Figure 7) was coincident with higher values of $\mathrm{Q}_{\text {Caracarani }}$ (Figures 5 and 6). Despite the fact that the alkalinity of the Caracarani River was moderate (20-232 $\mathrm{mg} \mathrm{CaCO}_{3} \cdot \mathrm{L}^{-1}$, see Table 1), its discharge contributed to increase $\mathrm{pH}$, thus an increase in turbidity. Overall, our results indicate that diurnal flow rate behavior controlled downstream $\mathrm{pH}$. Downstream $\mathrm{pH}$ triggers the precipitation of iron and aluminum mineral phases at streams affected by acid drainage $[42,43,46]$. In consequence, diurnal cycles in the formation of iron and aluminum phases, known to control the cycling of arsenic in the environment $[23,42,43,46-48]$, also constitute an important factor in the fate and transport of this toxic element.

\subsection{The Fate and Transport of Metals Controlled by Freeze-Thaw Cycles}

The effect diurnal changes in $\mathrm{pH}$ due to incoming flow ratios have on the fate of iron, aluminum, and arsenic can be visualized by comparing analyses of samples taken before and after the thawing of the Azufre River (Figure 9). A sample taken at 10:35 a.m. indicated a $\mathrm{pH}$ value of 5.2 and turbidity value of $45 \mathrm{NTU}$, dropping to $\mathrm{pH} 2.3$ and turbidity of $13 \mathrm{NTU}$ at 11:10 a.m. Total concentrations of iron, aluminum, and arsenic were considerably lower at 10:35 a.m. than those measured at 11:10 a.m. (5.4 vs. $22.2 \mathrm{mg} \cdot \mathrm{L}^{-1}$ of total $\mathrm{Fe}, 14.7$ vs. $58.5 \mathrm{mg} \cdot \mathrm{L}^{-1}$ of total $\mathrm{Al}$, and 0.18 vs. $0.63 \mathrm{mg} \cdot \mathrm{L}^{-1}$ of As). Moreover, particulate fractions were much higher when higher $\mathrm{pH}$ values were measured, as shown in Figure 9. The abrupt increase in metal concentrations occurred within the same time range when the higher inflow of the Azufre River was observed. The sudden inflow of the Azufre River was not only higher in flow rate, but also carried higher concentrations of chemical species, explaining the higher concentration of iron, aluminum, and arsenic. This explains why higher total flux occurred within a matter of minutes in a pulse-like manner. Additionally, low $\mathrm{pH}$ promotes the dissolution of iron and aluminum mineral phases (iron and aluminum hydroxides), increasing concentration of dissolved metals, a condition that does not favor arsenic sorption $[47,48]$. This comparison of samples, taken with only an hour from each other, showed that important changes in water quality are caused by diurnal variations in stream flow rate, particularly due to freeze and thaw cycles. 
(a)

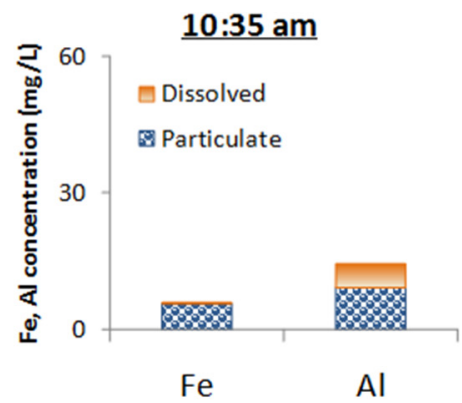

$\underline{11: 10 \mathrm{am}}$

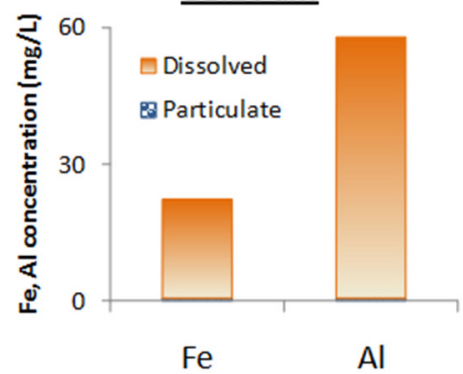

10:35 am

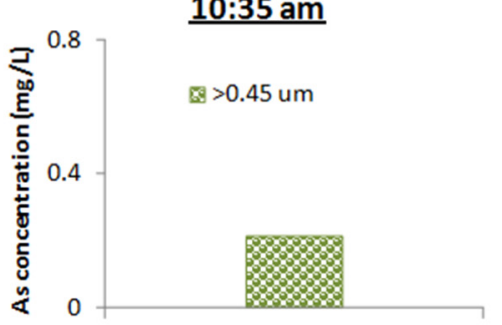

As

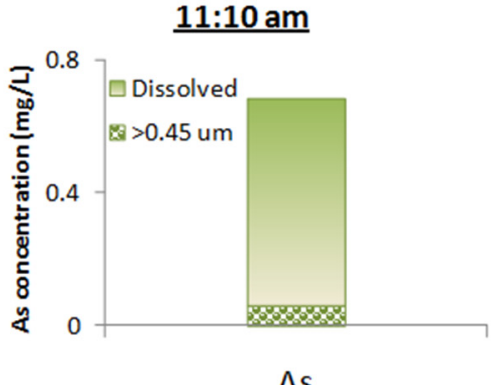

As

Figure 9. Aqueous concentrations of iron, aluminum, and arsenic downstream from the confluence before (10:35 a.m.) (a) and after (11:10 a.m.) (b) the pulse-type discharge of the Azufre River

The mass rate of elements depends on both the concentration of total suspended solids (TSS) and the concentration of metals. This was determined by estimating the rate of iron, aluminum, and arsenic in $\mathrm{g} \mathrm{h}^{-1}$, as follows:

$$
\begin{gathered}
\text { Mass rate of elements, } \mathrm{g} \cdot \mathrm{h}^{-1}=\left[\mathrm{TSS}, \mathrm{mg} \cdot \mathrm{L}^{-1}\right] \times\left[\text { Metal, } \mathrm{mg} \cdot \mathrm{kg}^{-1}\right] \times \\
\mathrm{Q}, \mathrm{L} \cdot \mathrm{h}^{-1} \times 10^{-9} \mathrm{mg} \cdot \mathrm{kg}^{-1},
\end{gathered}
$$

where TSS: concentration of total suspended solids, Element: concentration of the element (Fe, $\mathrm{Al}$ or As); $\mathrm{Q}$ : stream flowrate of the Caracarani River downstream from the confluence.

Indeed, arsenic reached its maximum concentration in the solid phase at $\mathrm{pH} 3.8$ (Table 2); however, the observed concentration of total suspended solids was only $9 \mathrm{mg} / \mathrm{L}$. The highest concentration of suspended solids ( $81 \mathrm{mg} / \mathrm{L}$ ) occurred at $\mathrm{pH}$ 5.9. Results showed that the mass rate of arsenic, iron, and aluminum in the solid phase, at a constant flowrate of $200 \mathrm{~L} \cdot \mathrm{s}^{-1}$, increased with a higher concentration of suspended solids, as shown in Figure 10. This means that the higher the concentration of total suspended solids, the higher the mass rate of elements in solid phase will be. Values of particulate and dissolved fractions of arsenic downstream from the Azufre River-Caracarani River confluence were presented in Guerra et al. [39]. Particulate arsenic concentration ranged between $75 \%$ and $95 \%$ within a wide range of $\mathrm{pH}$ values ( $\mathrm{pH} 3$ to 7 ); there was no increase or decrease of particulate arsenic concentration with increasing $\mathrm{pH}$. This indicates that particulate arsenic transport, in $\mathrm{g} \cdot \mathrm{h}^{-1}$, was controlled by the concentration of total suspended solids, which is a result of the $\mathrm{pH}$ of the stream. Immobilization of arsenic is promoted through the precipitation of mineral phases, reflected in the increased concentration of suspended solids. This is favorable in terms of site remediation: when iron and aluminum are part of the solid phase, these have the potential to settle on the stream bed. As arsenic sorption occurs, this metalloid will also be immobilized. Additionally, arsenic and iron were highly correlated (Figure 10), reaffirming the role of iron phases downstream from the confluence. A controlling factor in the fate of arsenic is the sorption or co-precipitation onto freshly precipitated iron and aluminum mineral phases (hydroxides and hydrosulfates) [42,45]. In the case of the Azufre River-Caracarani River confluence, diurnal changes in flowrate (in consequence, in the proportion $\mathrm{Q}_{\text {Azufre }} /\left(\mathrm{Q}_{\text {Azufre }}+\mathrm{Q}_{\text {Caracarani }}\right)$ control downstream $\mathrm{pH}$. $\mathrm{pH}$ triggers reactions of precipitation of iron 
and aluminum phases. In consequence, particulate arsenic (sorbed or co-precipitated onto mineral phases) is also prone to experience diurnal cycles. During the hours when $Q_{\text {Azufre }}$ is at peak values, iron hydroxides are dissolved, and, as a consequence, arsenic is again released into the aqueous phase. For this reason, the estimation of the mass rate of elements in solid phase $\left(\mathrm{g} \cdot \mathrm{h}^{-1}\right)$ is relevant, in order to determine at which moments of the day arsenic transport is promoted.

An integration of the hydrologic and chemical processes that were described can be presented through a conceptual model, as shown in Figure 11. When $Q_{\text {Azufre }} /\left(Q_{\text {Azufre }}+Q_{\text {Caracarani }}\right)$ is high, $\mathrm{pH}$ is low and, as a consequence, so is the concentration of total suspended solids (surrogate for iron and aluminum mineral phases). At a low pH, total arsenic is high (Figure 9) and the low availability of solid phases indicates that the particulate arsenic mass rate is low (thus, dissolved arsenic will be high). When $\mathrm{Q}_{\text {Azufre }} /\left(\mathrm{Q}_{\text {Azufre }}+\mathrm{Q}_{\text {Caracarani }}\right)$ is lower, $\mathrm{pH}$ is higher and, as a consequence, the formation of mineral phases is promoted. At higher $\mathrm{pH}$ values, total arsenic is lower (Figure 9), and the higher availability of mineral phases promotes arsenic sorption. This indicates that the particulate arsenic mass rate is higher at these conditions.

This study shows how cycles in flow rate, due to daily freeze-thaw processes, can also constitute a controlling factor in the fate and transport of toxic elements downstream a confluence affected by acid drainage. It is also necessary to consider these freeze-thaw processes and their effect in arsenic transport at distances further downstream the confluence. Modeling of arsenic-rich sediments at a future reservoir located downstream, at the Lluta Valley, showed the potential desorption of arsenic from the sediments [49]; the cyclic transport of dissolved or particulate arsenic may also have effects on the chemical dynamics of reservoirs near areas affected by acid drainage.

(a)
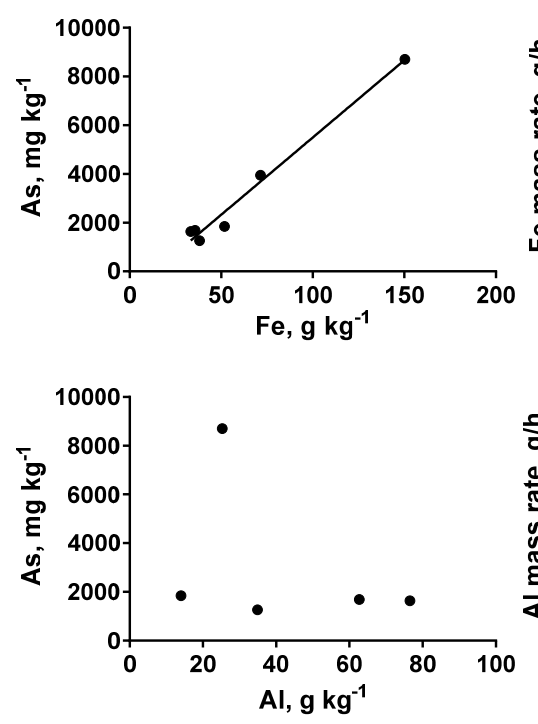

(b)
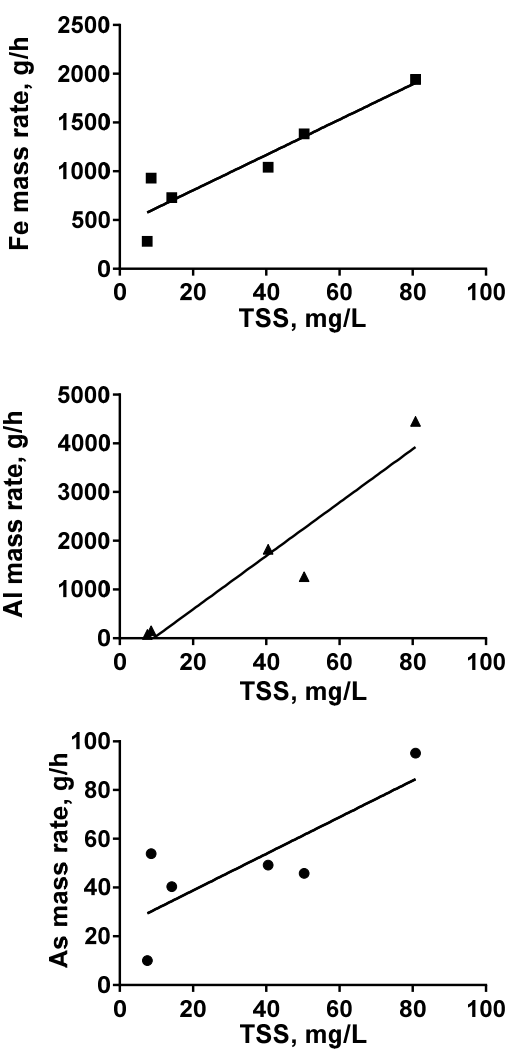

Figure 10. Arsenic, iron and aluminum in the solid phase. Relation between arsenic concentration in the solid phase and iron and aluminum concentration in the solid phase (a). Mass rate of metals versus total suspended solids $(\mathbf{b})$. 


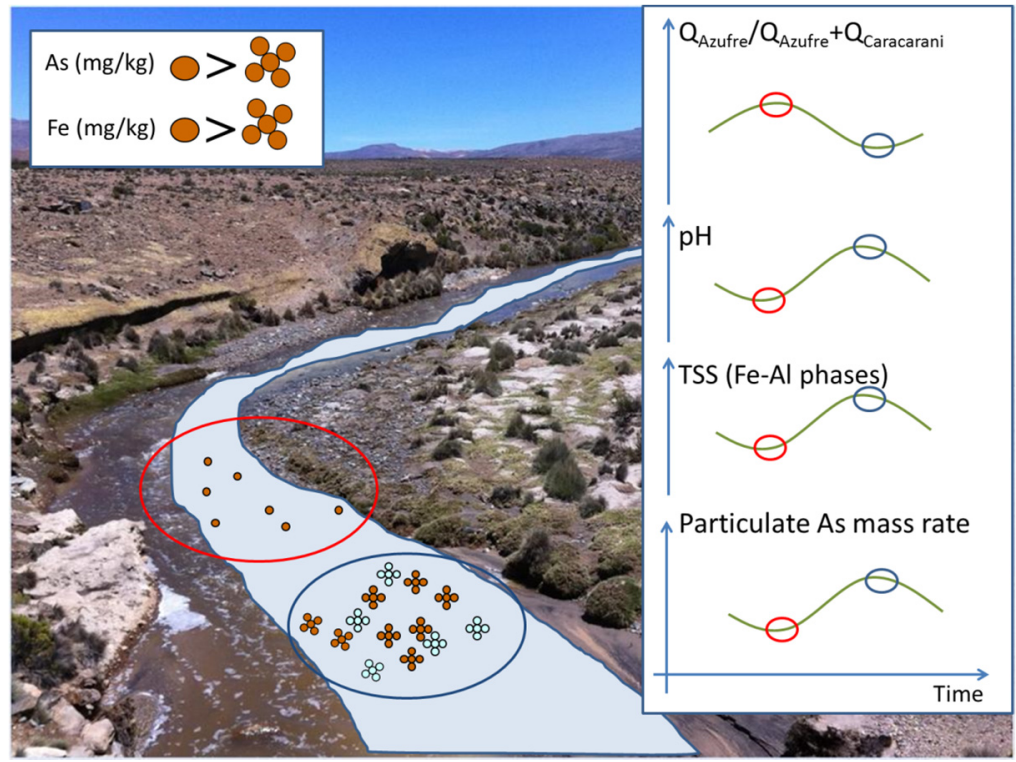

Figure 11. Conceptual model of the hydrologic and chemical processes that occur downstream from the Azufre River-Caracarani River confluence.

\section{Conclusions}

The objective of this paper was to show how daily variations in stream flow rates due to freeze and thaw cycles control metals' transport downstream in streams affected by acid drainage. We characterized the hydrologic and geochemical behavior of the Azufre River $(\mathrm{pH}<2)$ and Caracarani River ( $\mathrm{pH} \sim 8.6$ ) confluence (northern Chile) by measuring stream flow rates, temperature, electric conductivity, $\mathrm{pH}$, and turbidity and analyzing the concentration of metals in the aqueous phase. We showed how cyclic hydrological variations control the fate of contaminants in a watershed affected by acid drainage. Coincidental diurnal patterns were observed between flow rates, turbidity, and $\mathrm{pH}$. Important drops in $\mathrm{pH}$ occurred when peaks in $\mathrm{Q}_{\text {Azufre }}\left(\mathrm{Q}_{\text {Azufre }} /\left(\mathrm{Q}_{\text {Azufre }}+\mathrm{Q}_{\text {Caracarani }}\right)\right)$ occurred, with consequential drops in turbidity. Similarly, peaks in $\mathrm{pH}$ occurred within the same time range when the maximum $Q_{\text {Caracarani }}$ occurred, with consequential drops in turbidity. Changes in the flow rate of the Azufre River were caused by freeze and thaw cycles. The conclusions of this work are as follows:

1. Due to the below-zero temperatures reached at night, $Q_{\text {Azufre }}$ was controlled by daily freeze-thaw processes. The daily pulse in flow rate in the acid drainage results in a pulse in the flux of dissolved metals downstream and in the dissolution of suspended solids. Although this process occurred for only a few minutes every day, it was sufficient to mobilize metals and degrade water quality downstream due to, for example, higher flux of dissolved arsenic.

2. Diurnal behavior of water quality downstream from the confluence was controlled by diurnal changes in the upstream flow regime. Clear patterns in $\mathrm{pH}$ occurred concurrently with daily peaks in $Q_{\text {Azufre }}$ and $Q_{\text {Caracarani. }}$. As a consequence, turbidity (surrogate for suspended solids formed downstream as a consequence of the precipitation of mineral phases) also experience daily peaks. In this study, hourly variations at a confluence affected by acid drainage due to daily freeze and thaw cycles were identified, showing that drastic changes in water quality are not limited to seasonal factors (i.e., snow melts, increase in rainfall) but could occur within intraday time scales.

3. The formation of mineral phases downstream from the confluence was enhanced at distinct times of the day (dawn and mid-afternoon). Since the formation of suspended solids controlled the fate and transport of metals, attenuation of dissolved contaminants would improve within these time lapses, as particles have the potential to settle onto the streambed. 
Hydrologic diurnal cycles constitute an important factor to consider when exploring sites affected by acid drainage. Diurnal cycles in flow rate, particularly in streams affected by acid drainage, caused by freeze and thaw cycles are prone to occur at other sites where below-zero temperatures occur, such as mine sites located at high altitudes. The processes observed at this site impacted on the downstream water quality in a cyclical manner through daily "pulse-type" discharges. These diurnal changes may cause variability in the analysis of freshwater samples, critical in planning sampling and monitoring campaigns in these types of systems. The knowledge of when and where attenuation/mobilization of contaminants occurs is important to prevent toxic elements from reaching points of use for human consumption and agriculture.

Acknowledgments: We thank Marina Coquery and Jean-François Gaillard for their comments on our work. We also thank Alejandra Vega for providing hydrological data. This research was funded by Fondecyt 1130936/2013 and CONICYT-FONDAP 15110020. The CONICYT scholarship (folio number 2110173) is acknowledged by Paula Guerra.

Author Contributions: The manuscript was written by Paula Guerra, but all the authors contributed to its preparation and review. Hydrochemical field data was mainly obtained by Kyle Simonson. Data analyses were carried out by Paula Guerra in discussion with Jorge Gironas and Pablo Pasten.

Conflicts of Interest: The authors declare no conflict of interest.

Appendix A: Caracarani River and Azufre River flow rates, Azufre River temperature, Azufre River electric conductivity and mixing ratios arranged per month (January 2011-November 2011).

(a)

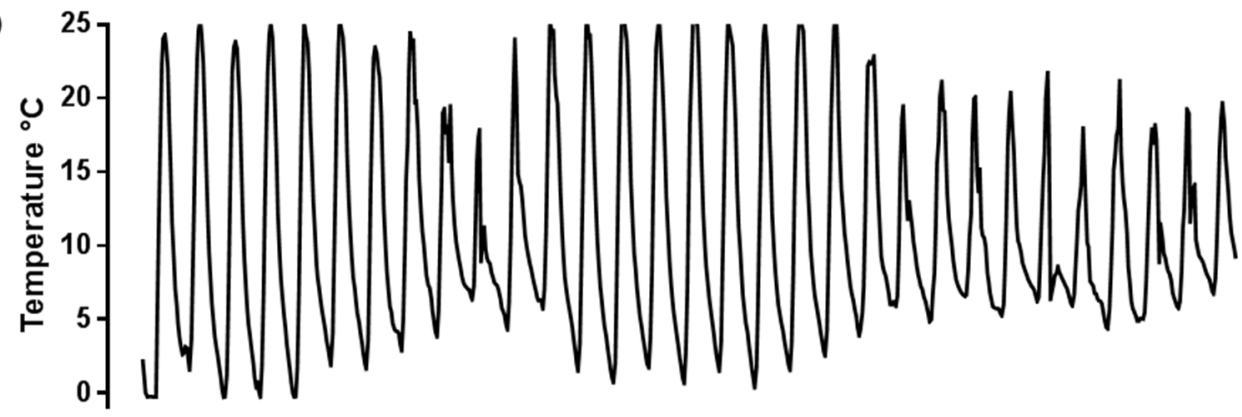

(b)

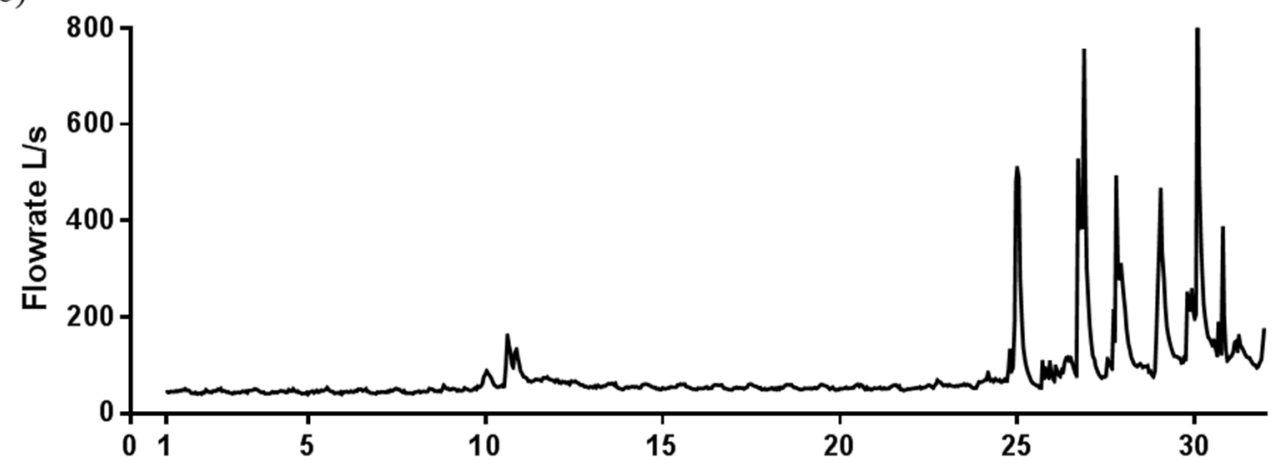

Figure A1. Hourly hydrological data from January 2011. (a) Azufre River temperature $\left(T_{A z u f r e}\right)$; (b) Azufre River $\left(Q_{A z u f r e}\right)$ flow-rates. The axis depicts the days of the month. $Q_{\text {Azufre }}$ was extrapolated for values greater than $250 \mathrm{~L} / \mathrm{s}$. 
(a)

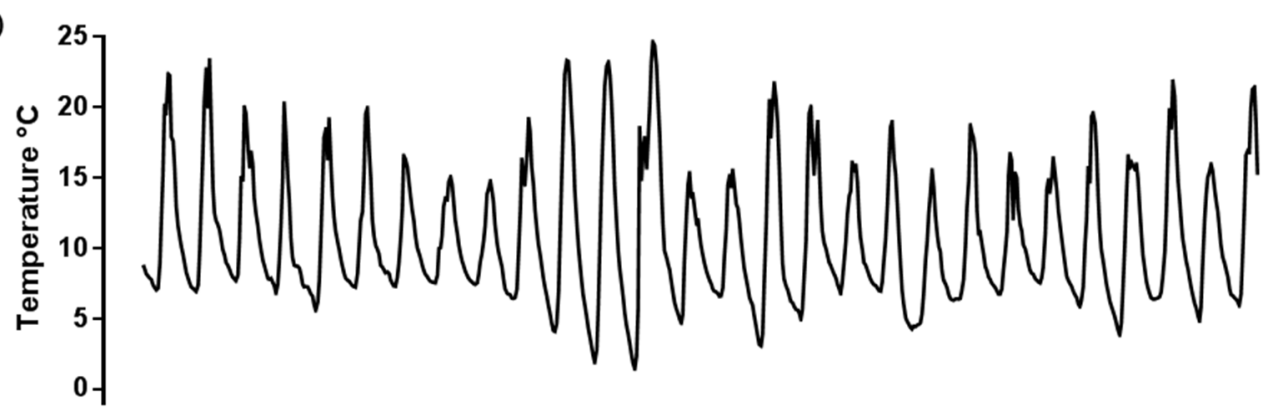

(b)

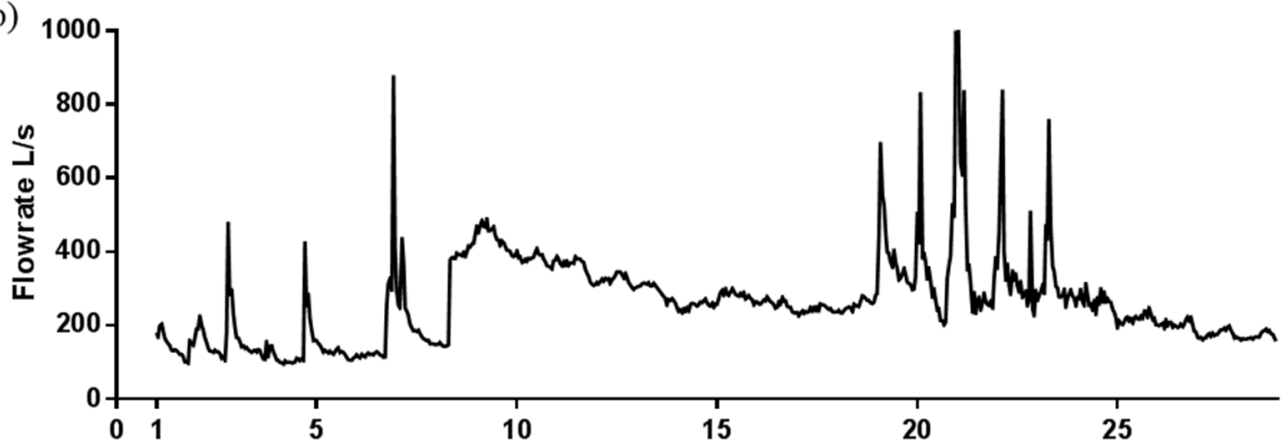

Figure A2. Hourly hydrological data from February 2011. (a) $T_{\text {Azufre }}$ (b) $Q_{\text {Azufre. }}$. The axis depicts the days of the month. $Q_{\text {Azufre }}$ was extrapolated for values greater than $250 \mathrm{~L} / \mathrm{s}$.

(a)

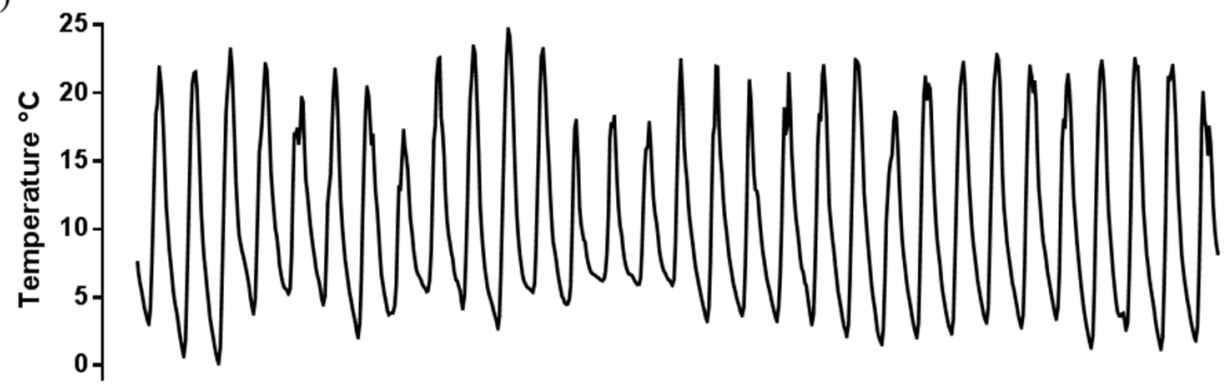

(b)

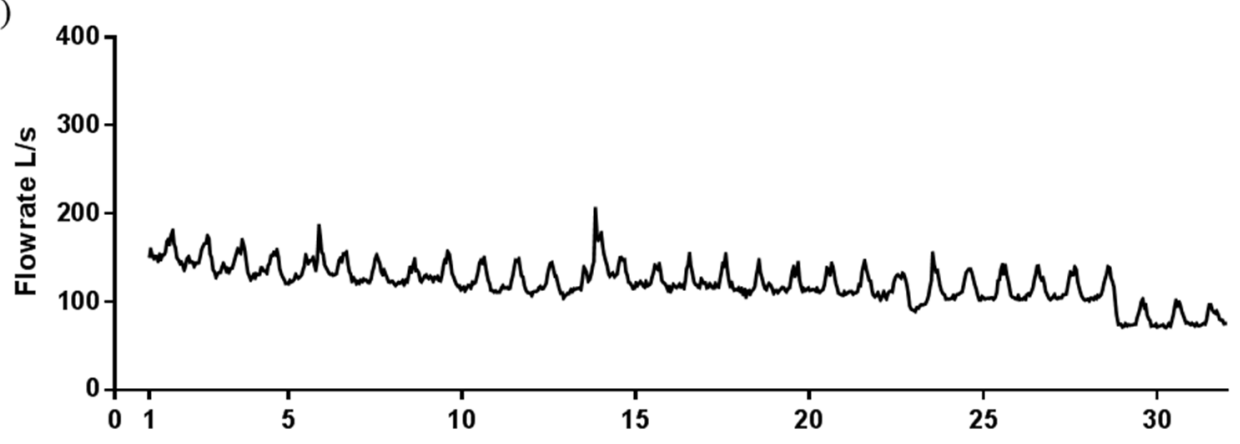

Figure A3. Hourly hydrological data from March 2011. (a) $T_{\text {Azufre }}$ (b) $\mathrm{Q}_{\text {Azufre. }}$ The axis depicts the days of the month. 
(a)

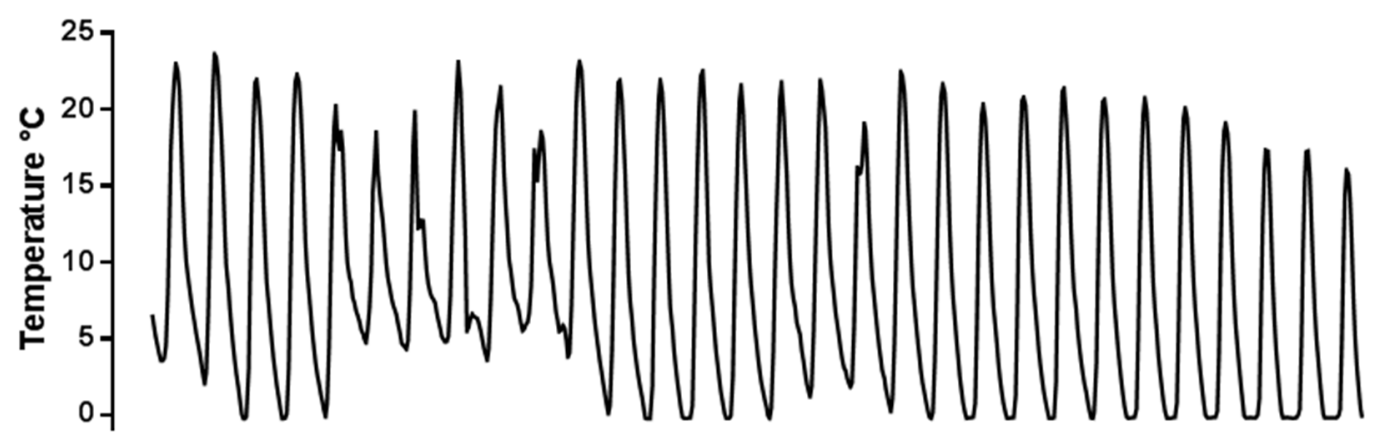

(b)

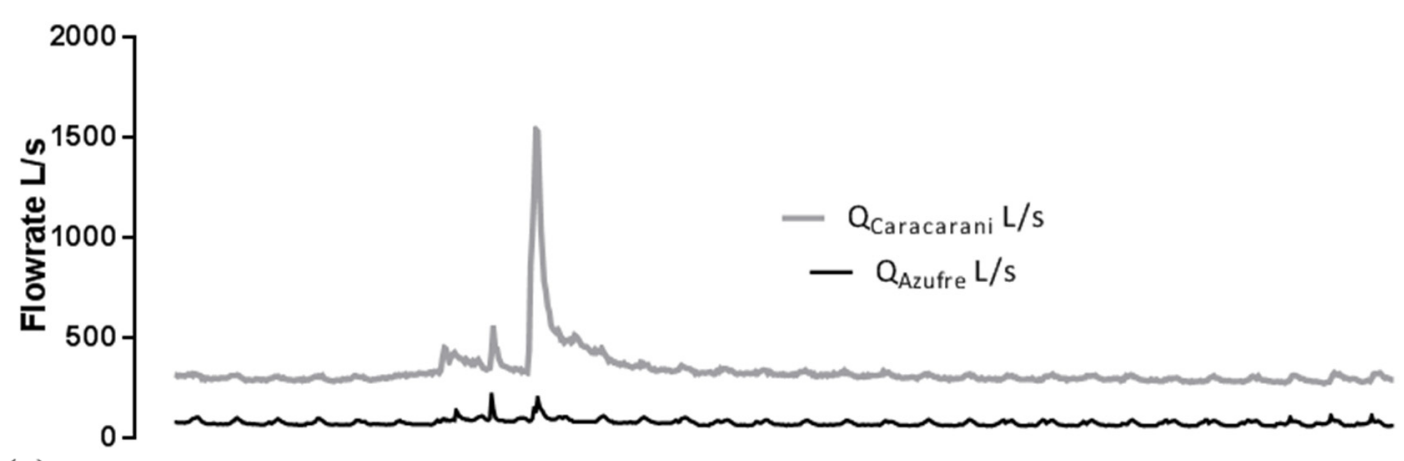

(c)

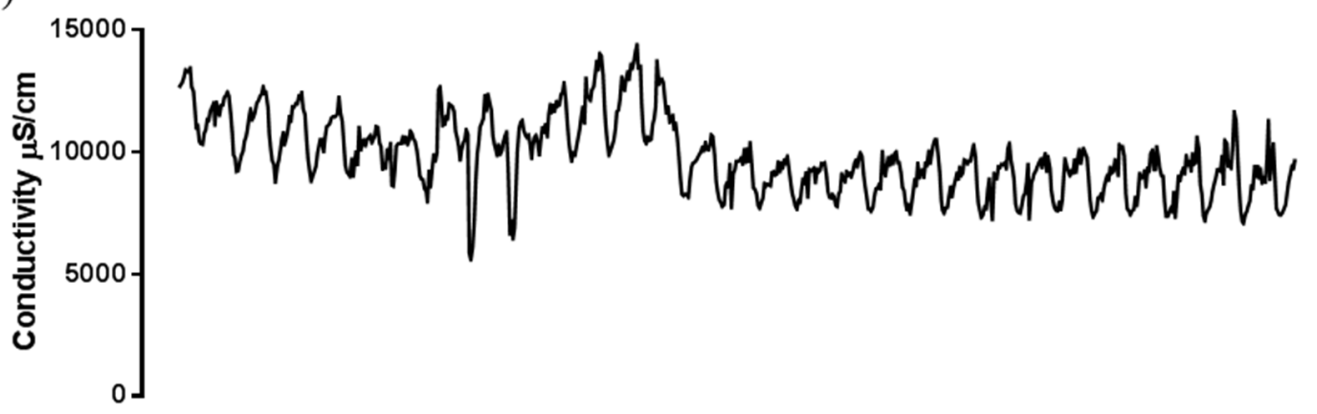

(d)

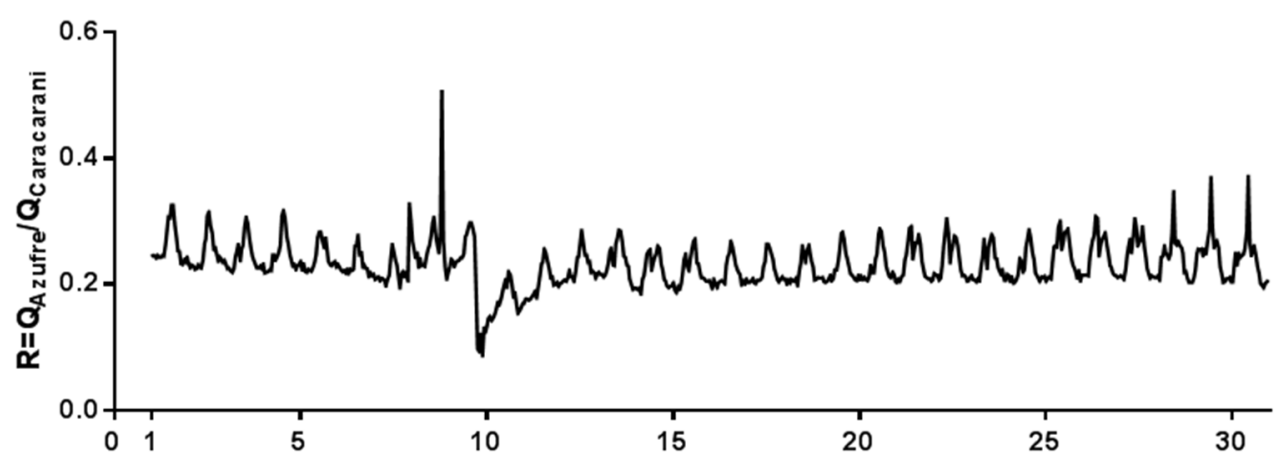

Figure A4. Hourly hydrological data from April 2011 (a) $T_{\text {Azufre }} ;\left(\right.$ b) $Q_{\text {Azufre }}$ and $Q_{\text {Caracarani }}$; (c) Mixing ratio $R$; (d) Azufre River electric conductivity $\left(E C_{A z u f r e}\right)$. The axis depicts the days of the month. $Q_{\text {Caracarani }}$ was extrapolated for values $>350 \mathrm{~L} / \mathrm{s}$. 
(a)

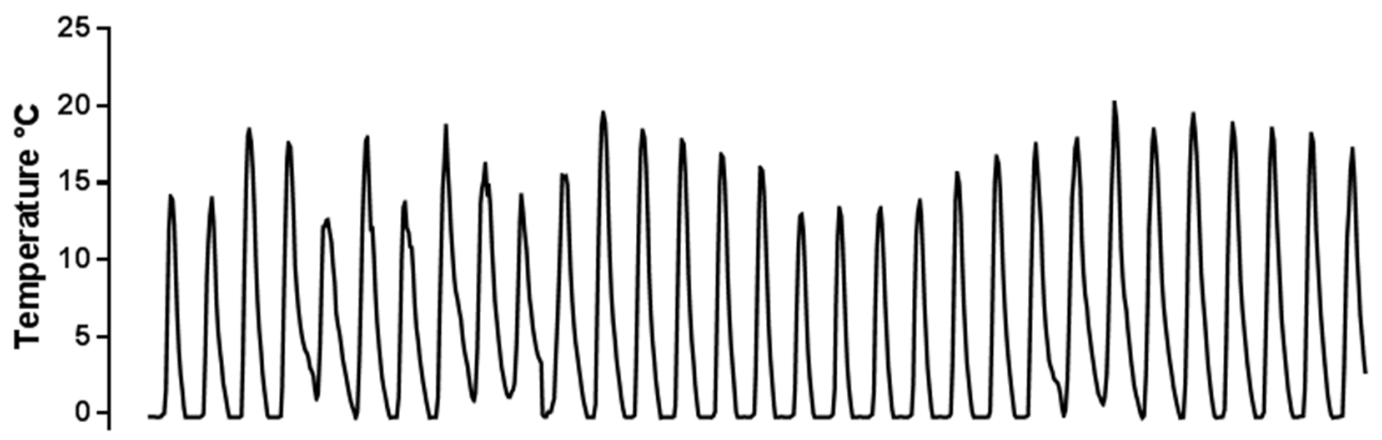

(b)

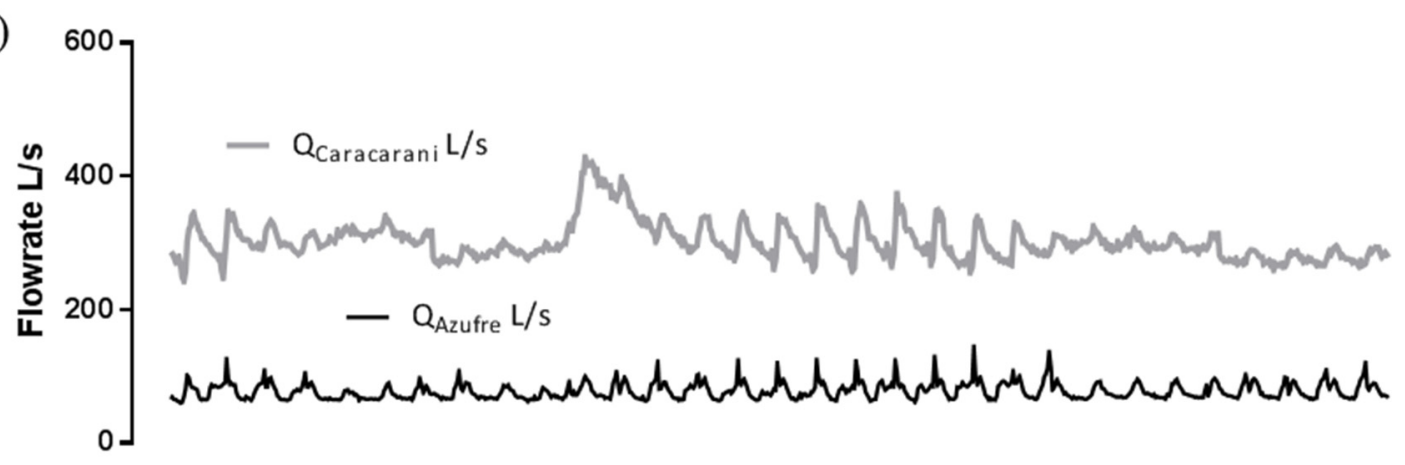

(c)

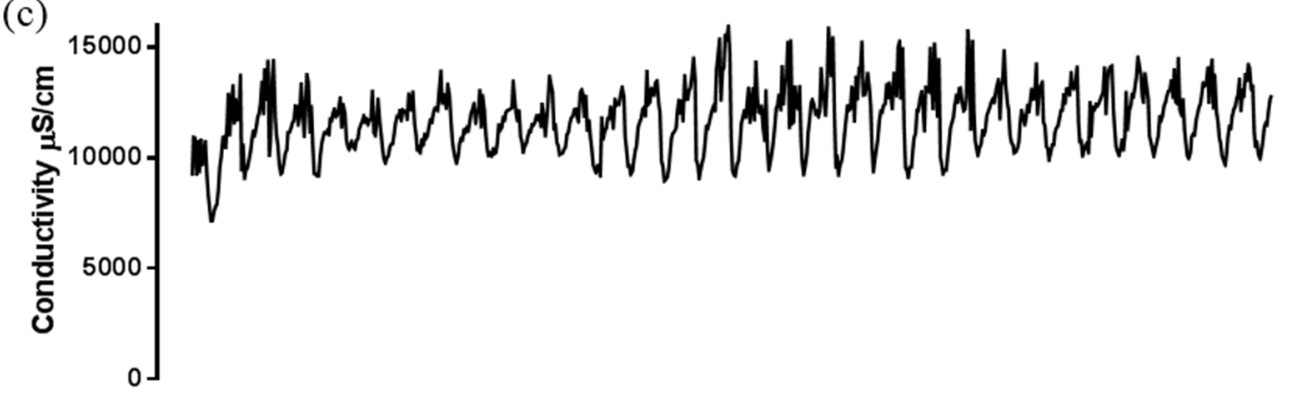

(d)

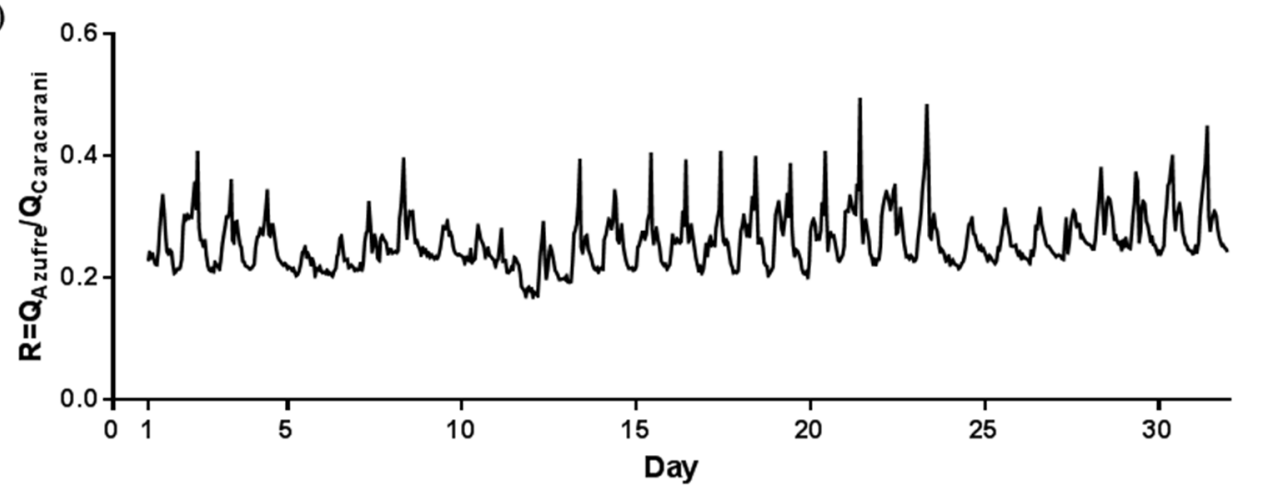

Figure A5. Hourly hydrological data from May 2011. (a) $T_{\text {Azufre }} ;$ (b) $Q_{\text {Azufre }}$ and $Q_{\text {Caracarani }}$; (c) Mixing ratio $R ;(\mathbf{d}) E C_{A z u f r e}$. The axis depicts the days of the month. $Q_{\text {Caracarani }}$ was extrapolated for values $>350 \mathrm{~L} / \mathrm{s}$. 
(a)

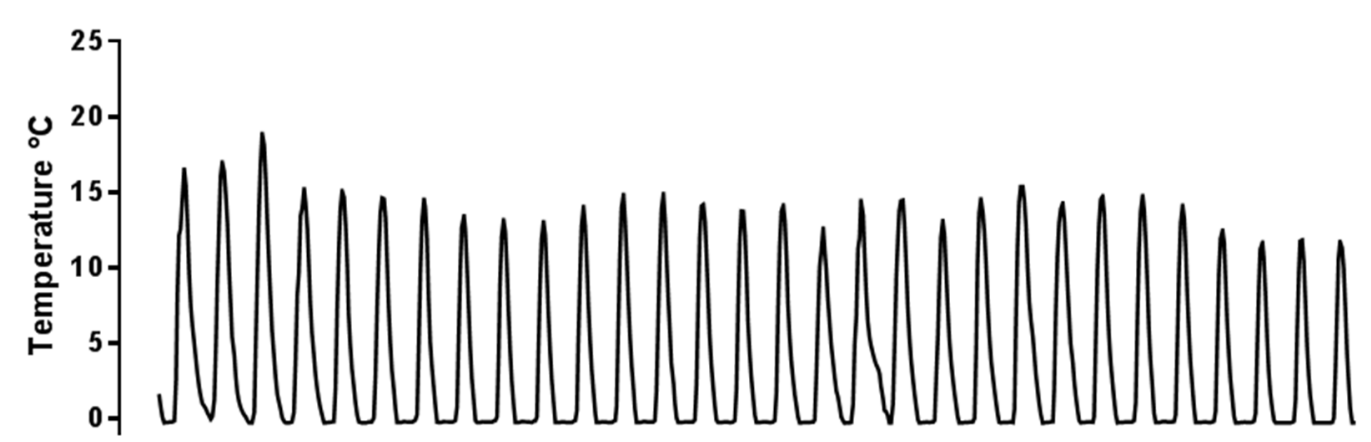

(b)

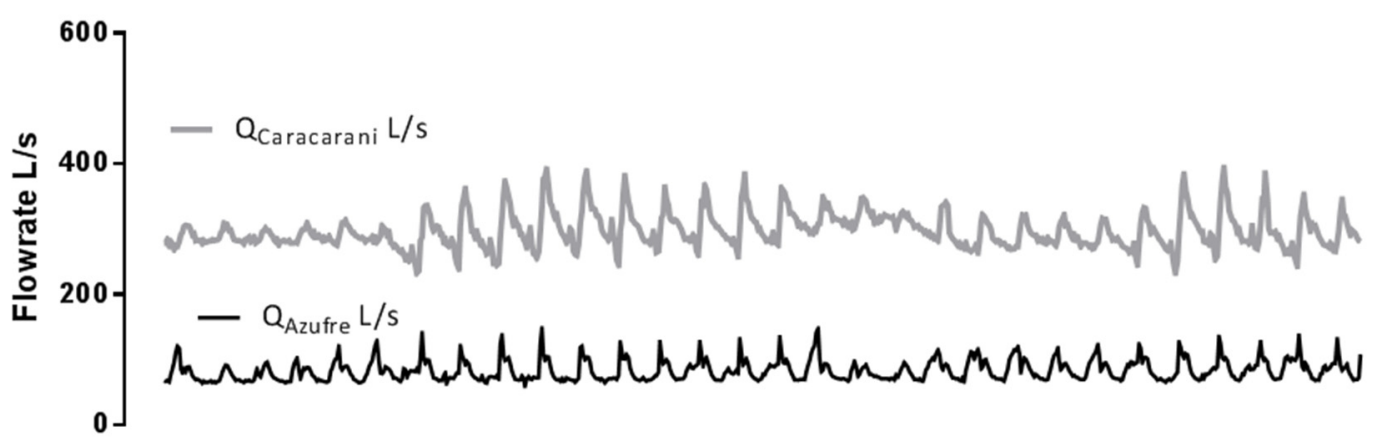

(c) 20000

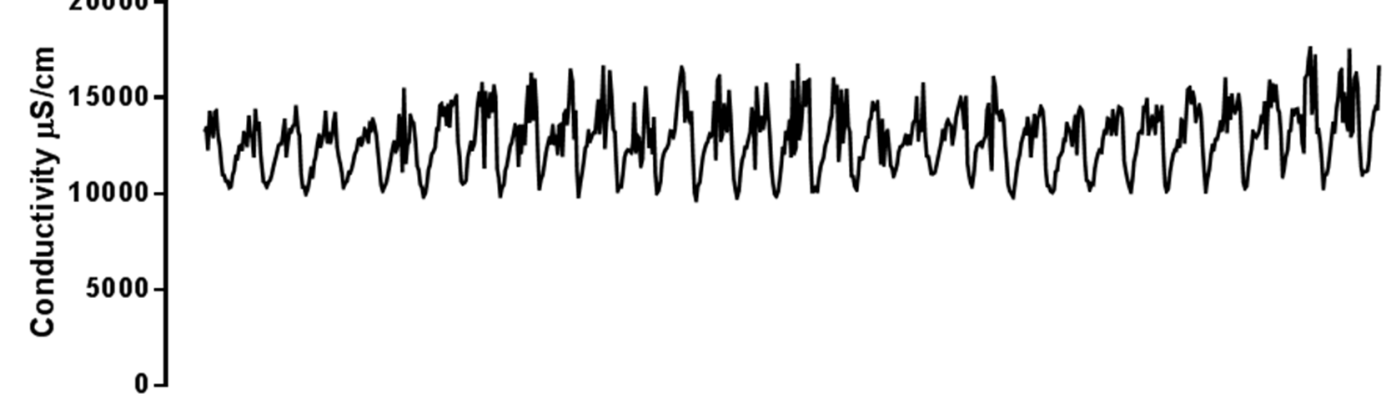

(d)

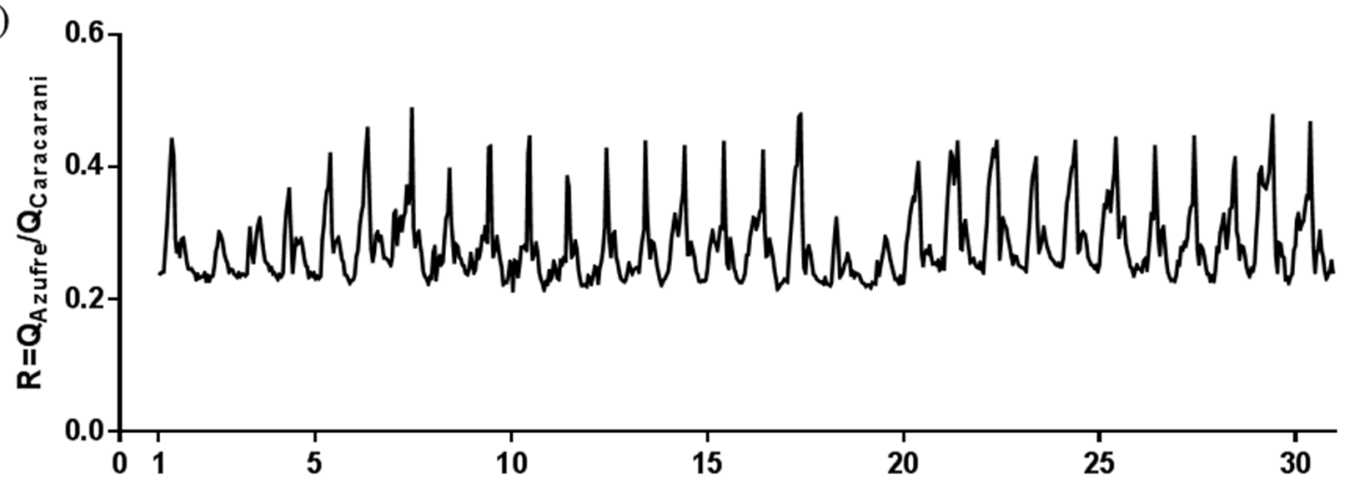

Figure A6. Hourly hydrological data from June 2011. (a) $T_{A z u f r e}$ (b) $\mathrm{Q}_{\text {Azufre; }}$ and $\mathrm{Q}_{\text {Caracarani; }}$; (c) Mixing ratio $R ;\left(\right.$ d) $E C_{\text {Azufre }}$. The axis depicts the days of the month. $Q_{\text {Caracarani }}$ was extrapolated for values $>350 \mathrm{~L} / \mathrm{s}$. 
(a)

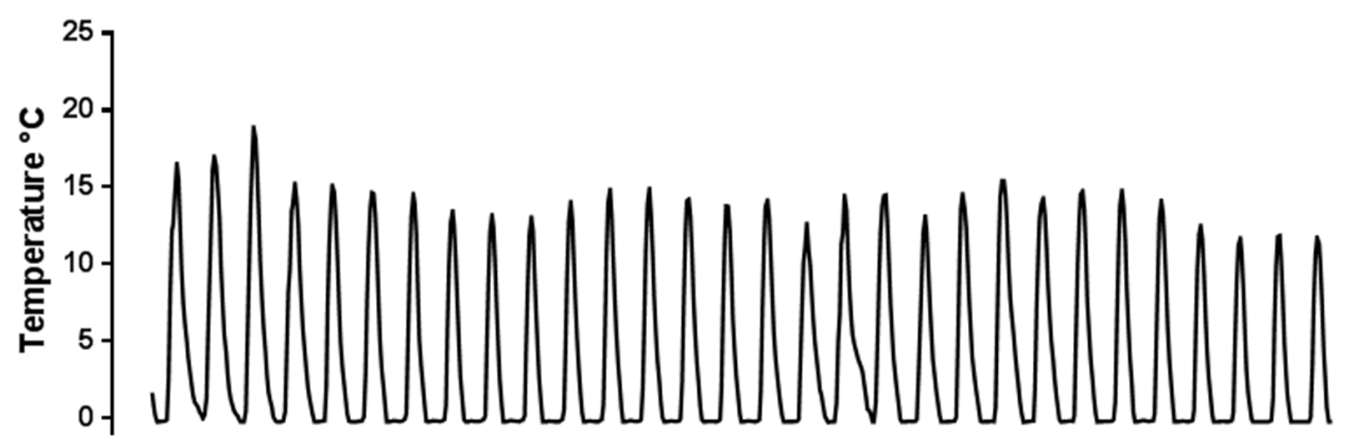

(b)

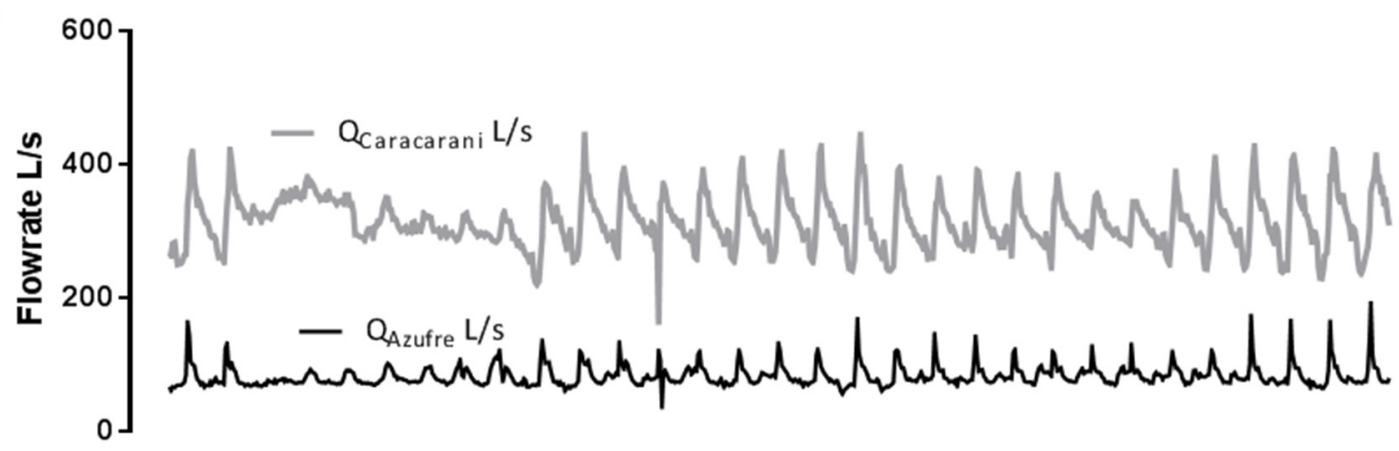

(c)

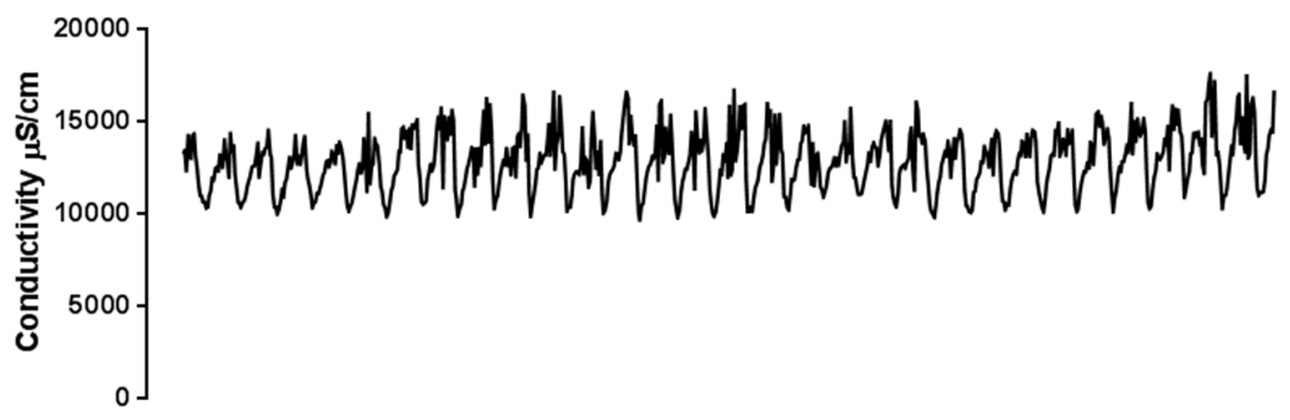

(d)

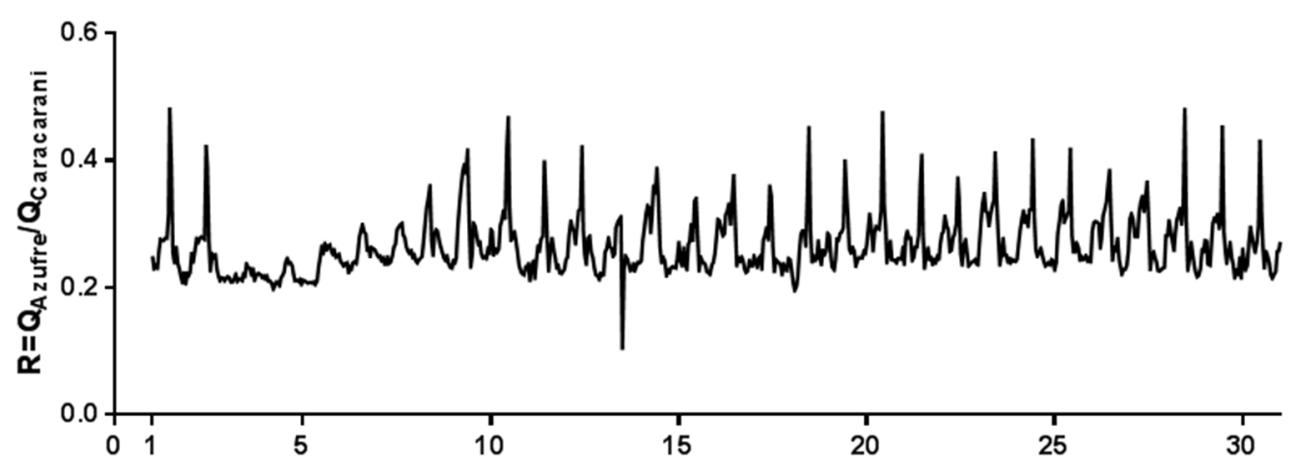

Figure A7. Hourly hydrological data from July 2011. (a) $T_{\text {Azufre }}$ (b) $Q_{\text {Azufre }}$ and $Q_{\text {Caracarani; }}$; (c) Mixing ratio $R ;$ (d) $E C_{\text {Azufre }}$. The axis depicts the days of the month. $Q_{\text {Caracarani }}$ was extrapolated for values $>350 \mathrm{~L} / \mathrm{s}$. 
(a)

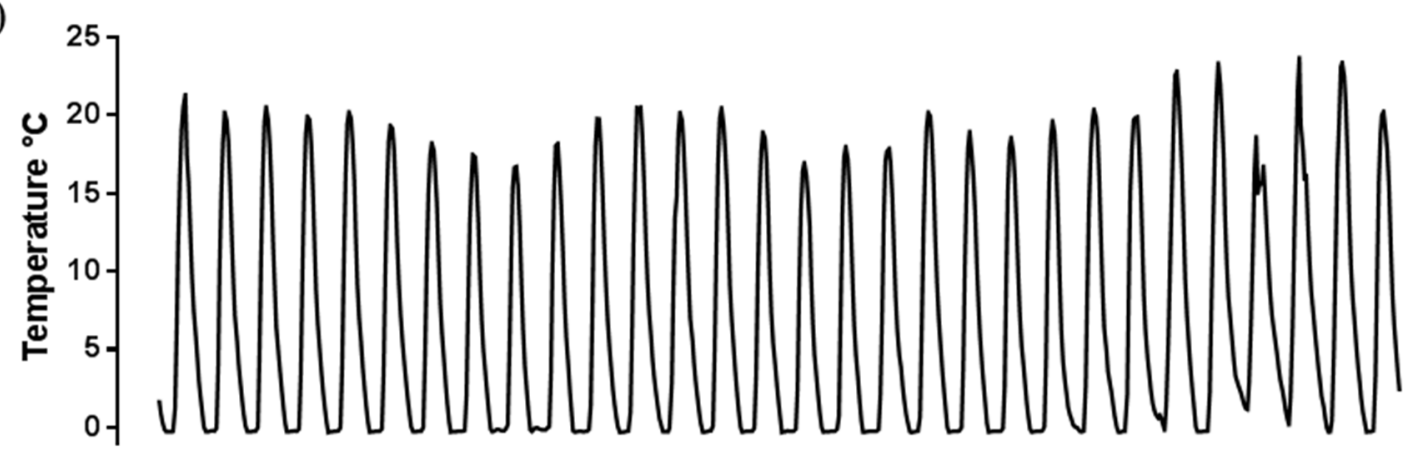

(b)

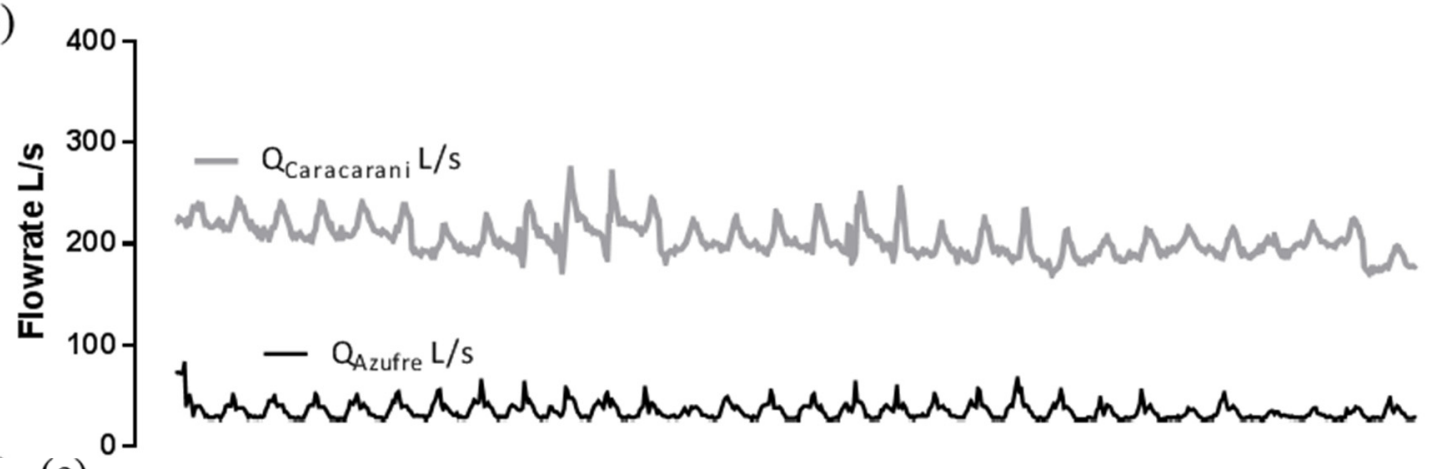

(c)

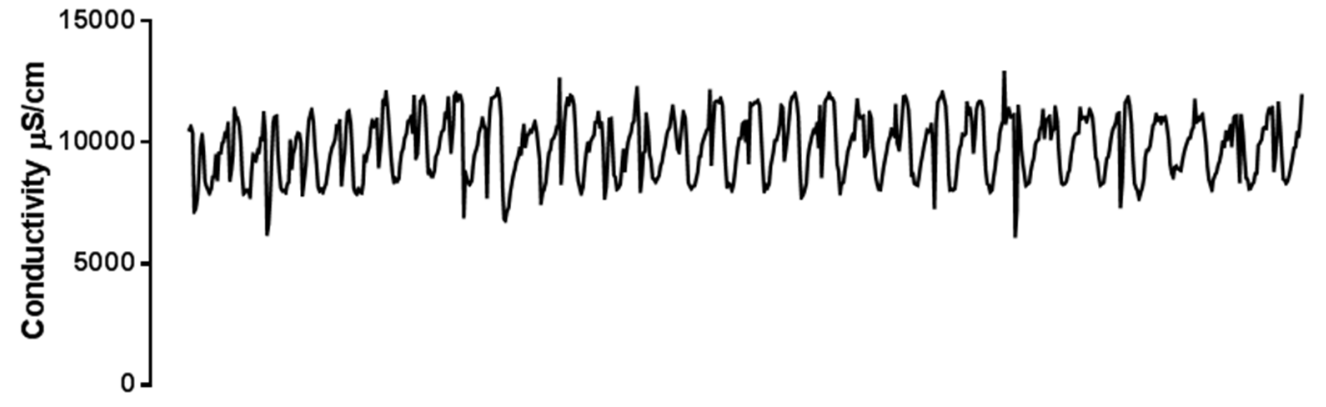

(d)

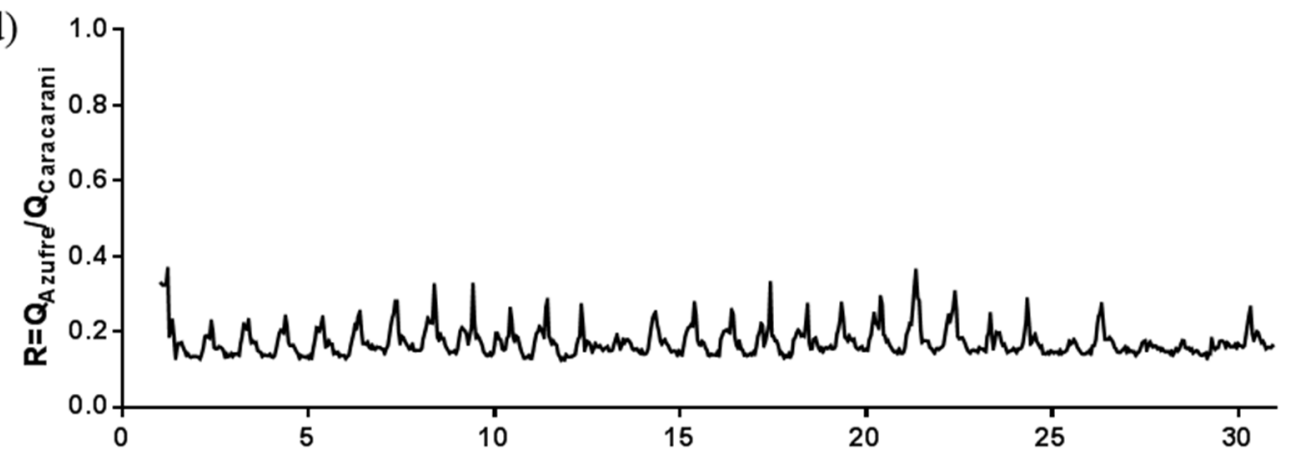

Figure A8. Hourly hydrological data from September 2011. (a) $T_{A z u f r e} ;$ (b) $Q_{\text {Azufre }}$ and $Q_{\text {Caracarani; }}$; (c) Mixing ratio $R ;$ (d) $E C_{A z u f r e}$. The axis depicts the days of the month. 
(a)

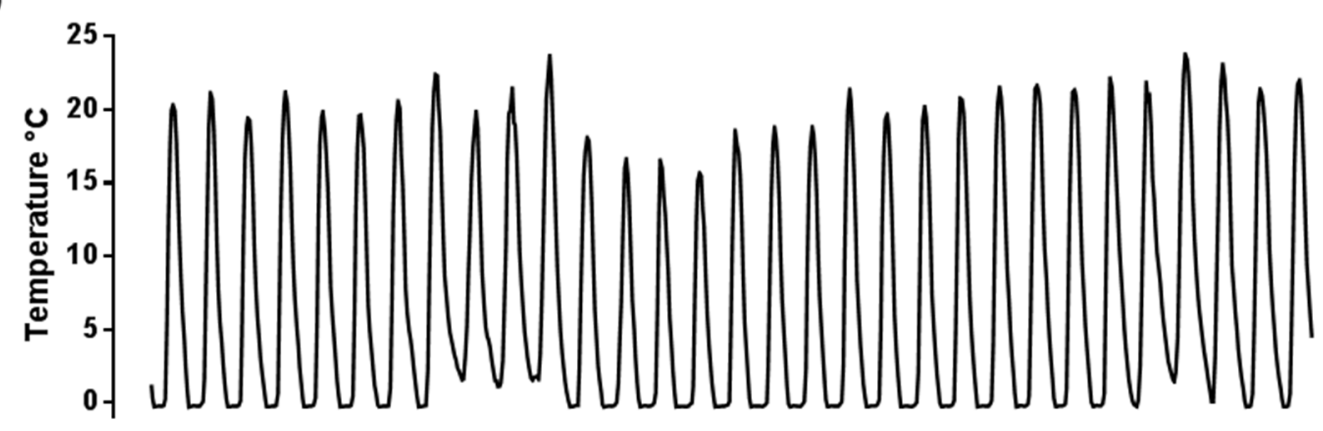

(b)

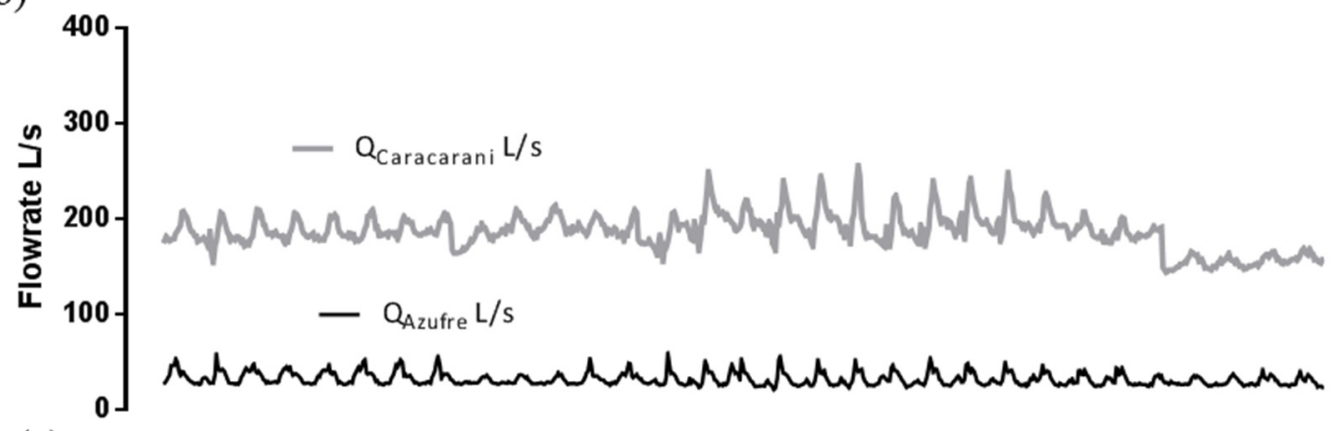

(c)
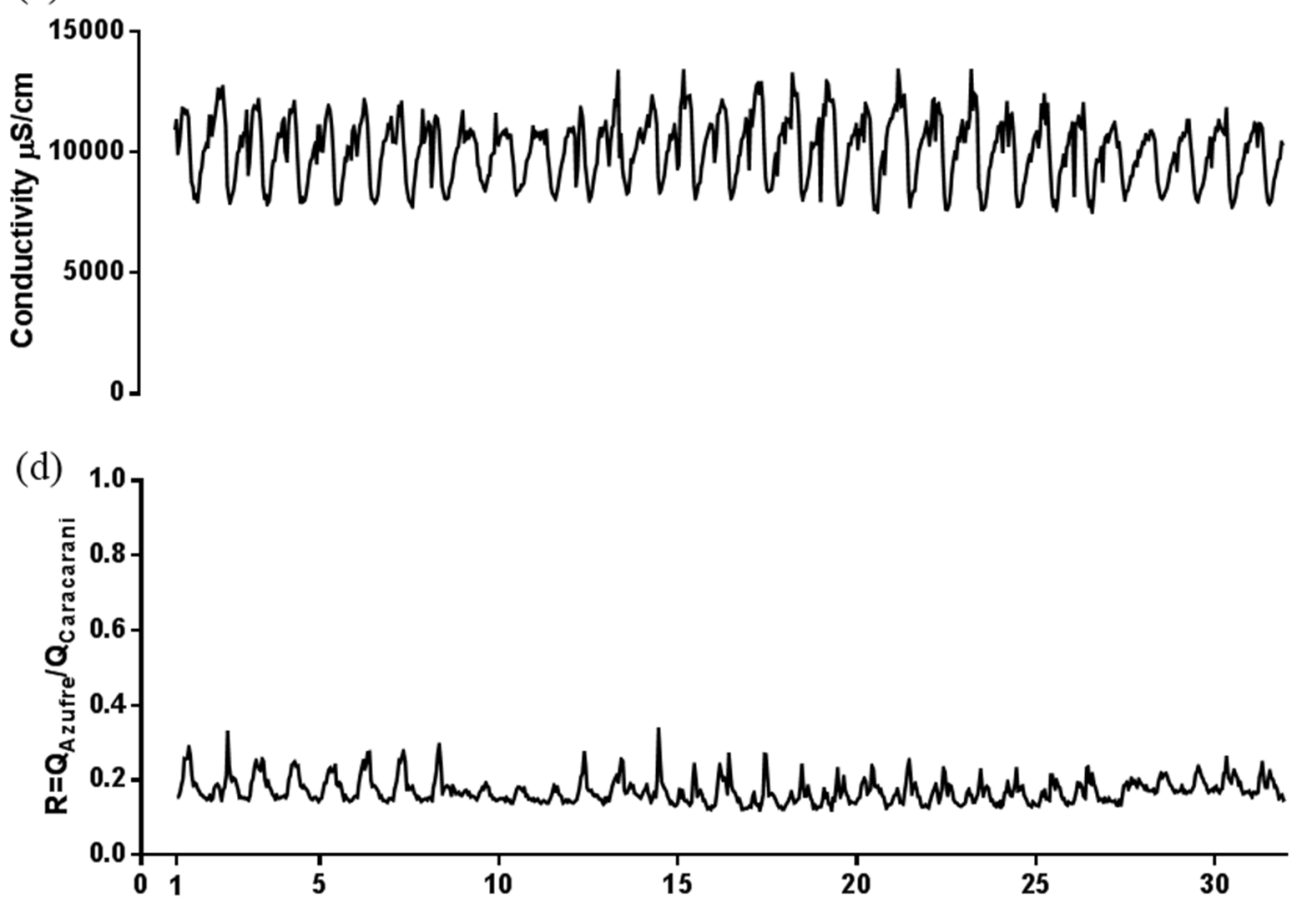

Figure A9. Hourly hydrological data from October 2011. (a) $T_{\text {Azufre }}$ (b) $\mathrm{Q}_{\text {Azufre }}$ and $Q_{\text {Caracarani; }}$; (c) Mixing ratio $R ;$ (d) $E C_{A z u f r e}$. The axis depicts the days of the month. 
(a)

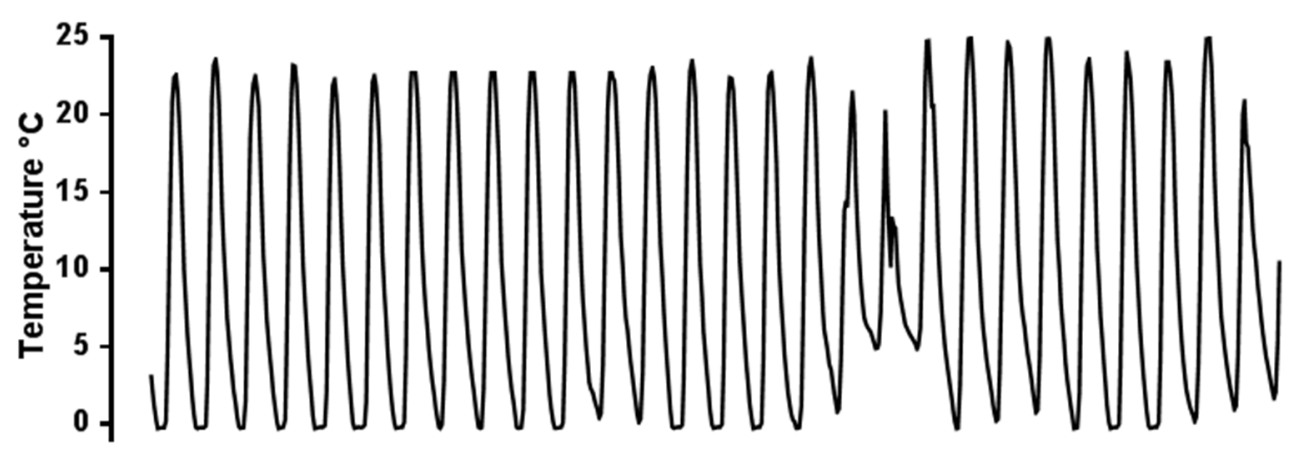

(b)

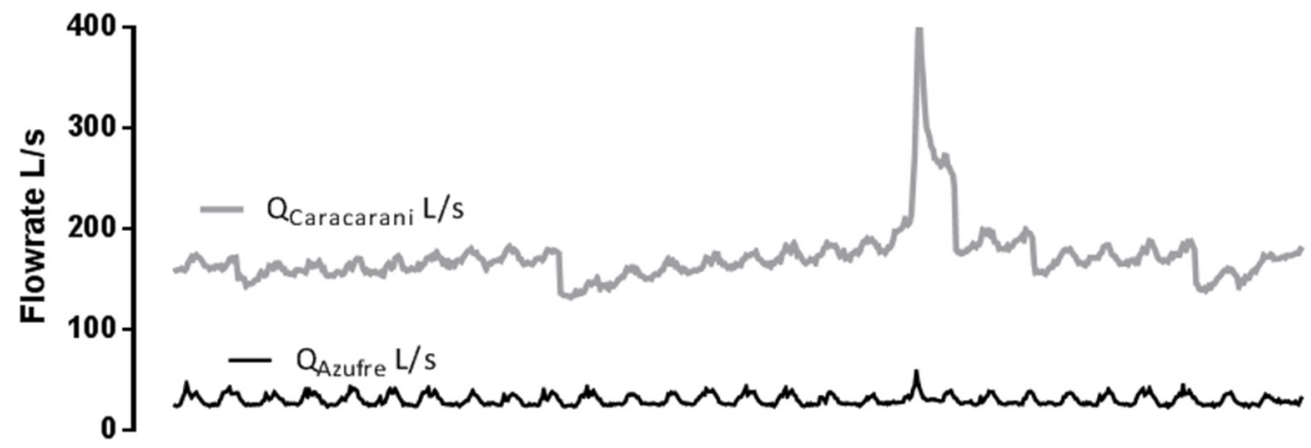

(c)

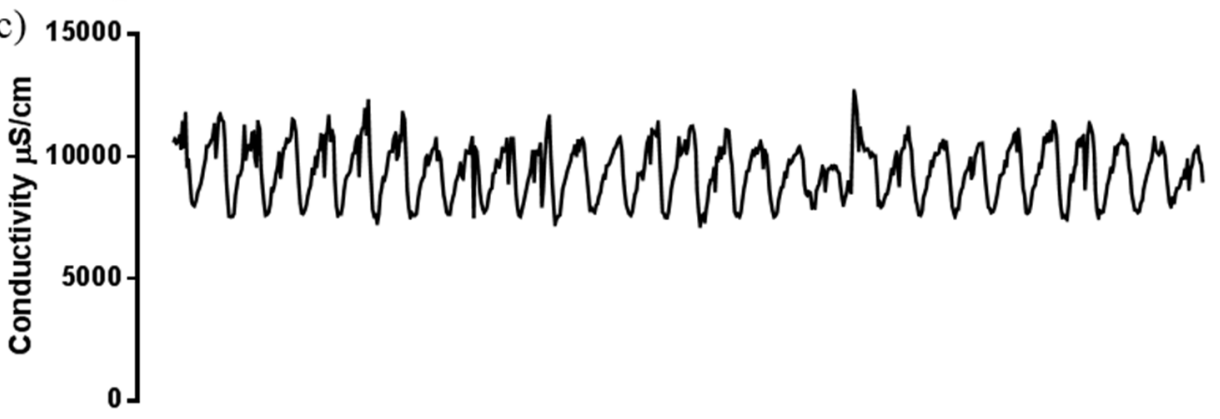

(d)

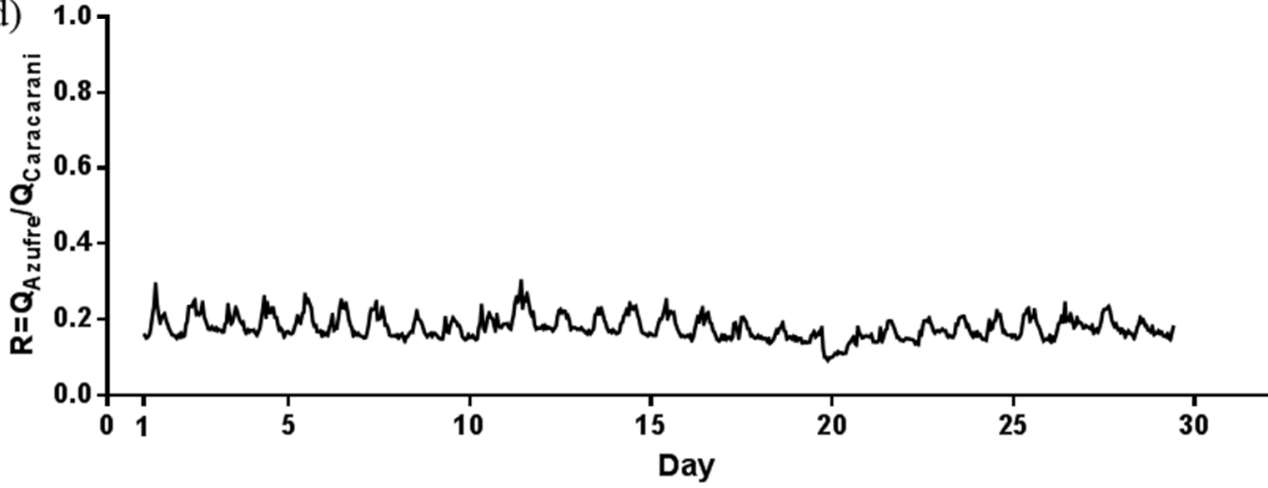

Figure A10. Hourly data from November 2011. (a) $T_{A z u f r e ;}$ (b) $Q_{A z u f r e}$ and $Q_{\text {Caracarani }}$; (c) Mixing ratio $R ;$ (d) $E C_{\text {Azufre }}$. The axis depicts the days of the month. $Q_{\text {Caracarani }}$ was extrapolated for values $>350 \mathrm{~L} / \mathrm{s}$. 
Appendix B: Turbidity and pH data from the Azufre River and Caracarani River (upstream of the confluence).

(a)
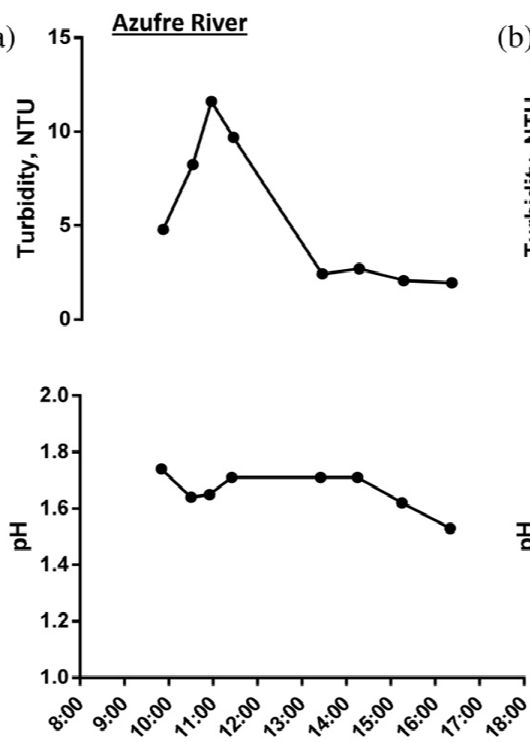

(b)
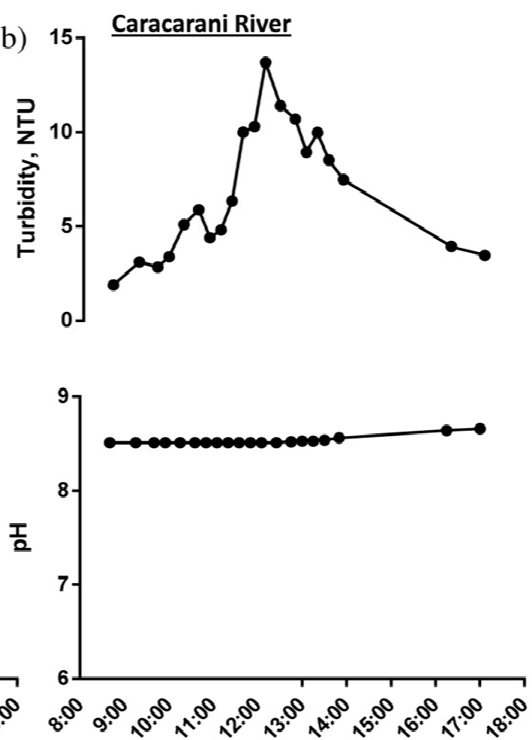

Figure B1. Daily turbidity and $\mathrm{pH}$ time series measured upstream of the confluence at the Azufre River (a) and Caracarani River (b). pH remained relatively constant in both cases, whereas turbidity reached a peak at around 12 p.m. and 11 a.m., respectively.

Appendix C: Preliminary geochemical model.

To build a preliminary geochemical model, the main reactions considered were the precipitation of $\mathrm{Fe}(\mathrm{OH})_{3(\mathrm{am})}$ and $\mathrm{Al}(\mathrm{OH})_{3(\mathrm{a})}$. A chemical equilibrium model for downstream mixing was developed to simulate the formation of these as freshly precipitated phases as a function of the mixing ratio $\left(\mathrm{V}_{\text {Azufre }} / \mathrm{V}_{\text {Caracarani }}\right)$. The $\mathrm{pH}$ was also simulated. The water quality considered for simulations is summarized in Table C1. The calculations were performed using the PHREEQC code (Parkhurst and Appelo, 1999) and wateq4f.dat thermodynamic database (Dzombak and Morel, 1990). Figure C1 describes the geochemical model. Other phases are relevant to systems affected by acid drainage (such as Schwertmannite and Basaluminite) and must be considered further to improve the current model.

Table C1. Representative water quality of the Azufre River and Caracarani River used to simulate the $\mathrm{pH}$ concentration of $\mathrm{Fe}(\mathrm{OH})_{3(\mathrm{am})}+\mathrm{Al}(\mathrm{OH})_{3(\mathrm{am})}$ using the PHREEQC code.

\begin{tabular}{cccc}
\hline Parameter & Unit & Azufre River & Caracarani River \\
\hline $\mathbf{p H}$ & - & 2.2 & 8.7 \\
Temperature & ${ }^{\circ} \mathrm{C}$ & 10 & 10 \\
Alkalinity & $\mathrm{mg} \mathrm{CaCO} / \mathrm{L}$ & 0 & 200 \\
$\mathbf{S O}_{4}^{-2}$ & $\mathrm{mg} / \mathrm{L}$ & 2450 & 477 \\
$\mathrm{Cl}^{-}$ & $\mathrm{mg} / \mathrm{L}$ & 920 & 190 \\
$\mathbf{N a}^{+}$ & $\mathrm{mg} / \mathrm{L}$ & 333 & 170 \\
$\mathbf{K}^{+}$ & $\mathrm{mg} / \mathrm{L}$ & 88 & 20 \\
$\mathbf{C a}^{+2}$ & $\mathrm{mg} / \mathrm{L}$ & 233 & 120 \\
$\mathbf{M g}^{+2}$ & $\mathrm{mg} / \mathrm{L}$ & 159 & 55 \\
Total Fe & $\mathrm{mg} / \mathrm{L}$ & 49 & 0.9 \\
Total Al & $\mathrm{mg} / \mathrm{L}$ & 156 & 0.7 \\
Total As & $\mathrm{mg} / \mathrm{L}$ & 2.1 & 0.05 \\
\hline Total B & $\mathrm{mg} / \mathrm{L}$ & 19.7 & 3.3 \\
Total Zn & $\mathrm{mg} / \mathrm{L}$ & 9.8 & 0.1 \\
\hline
\end{tabular}


Mixing ratio $R$ between the stream flow rates:

$$
\begin{gathered}
R=\frac{Q_{\text {Azufre }}}{Q_{\text {Caracarani }}} \\
X_{\text {Azufre }}=\frac{Q_{\text {Azufre }}}{Q_{\text {Azufre }}+Q_{\text {Azufre }}} \\
X_{\text {Caracarani }}=\frac{Q_{\text {Caracarani }}}{Q_{\text {Azufre }}+Q_{\text {Azufre }}} \\
X_{\text {Azufre }}+X_{\text {Caracarani }}=1
\end{gathered}
$$

Calculation of total iron and aluminum concentrations:

$$
\begin{gathered}
\quad\left[\mathrm{Fe}^{+3}\right]_{\text {Total }}=\left[\mathrm{Fe}^{+3}\right]_{\text {Azufre }} \times X_{\text {Azufre }}+\left[\mathrm{Fe}^{+3}\right]_{\text {Caracarani }} \times X_{\text {Caracarani }} \\
\Rightarrow \quad\left[\mathrm{Al}^{+3}\right]_{\text {Total }}=\left[\mathrm{Al}^{+3}\right]_{\text {Azufre }} \times X_{\text {Azufre }}+\left[\mathrm{Al}^{+3}\right]_{\text {Caracarani }} \times X_{\text {Caracarani }} \\
{[\text { Alkalinity }]_{\text {Total }}=[\text { Alkalinity }]_{\text {Caracarani }} \times X_{\text {Caracarani }}}
\end{gathered}
$$

\section{$\Downarrow$}

pH and reactions of precipitation of amorphous phases:

$$
\begin{gathered}
\mathrm{pH}=-\log \left[\mathrm{H}^{+}\right] ;\left[\mathrm{H}^{+}\right]=f\left(\mathrm{R} \text {, alkalinity, }\left[\mathrm{O}_{2}\right],\left[\mathrm{CO}_{2}\right],[\mathrm{OH}]^{-}, \mathrm{Al}^{+3}, \mathrm{Fe}^{+3}\right) \\
\mathrm{Fe}^{+3}+3 \mathrm{H}_{2} \mathrm{O} \leftrightarrows \mathrm{Fe}(\mathrm{OH})_{3}(\mathrm{am})+3 \mathrm{H}^{+} \quad \mathrm{K}=10^{-4.89}\left(25^{\circ} \mathrm{C}\right) \\
\mathrm{Al}^{+3}+3 \mathrm{H}_{2} \mathrm{O} \leftrightarrows \mathrm{Al}(\mathrm{OH})_{3}(\mathrm{am})+3 \mathrm{H}^{+} \quad \mathrm{K}=10^{-10.8}\left(25^{\circ} \mathrm{C}\right)
\end{gathered}
$$

Figure C1. Conceptual model of the precipitation of $\mathrm{Fe}(\mathrm{OH})_{3(\mathrm{a})}$ and $\mathrm{Al}(\mathrm{OH})_{3(\mathrm{a})}$ as a function of the mixing ratio. $\mathrm{pH}$ was estimated as a function of coupled reactions that include precipitation and other acid-base reactions (i.e., carbonate system).

\section{References}

1. Aubert, A.H.; Gascuel-Odoux, C.; Merot, P. Annual hysteresis of water quality: A method to analyse the effect of intra- and inter-annual climatic conditions. J. Hydrol. 2013, 478, 29-39. [CrossRef]

2. Davies, T.D.; Tranter, M.; Blackwood, I.L.; Abrahams, P.W. The character and causes of a pronounced snowmelt-induced acidic episodes in a stream in a Scottish subarctic catchment. J. Hydrol. 1993, 146, 267-300. [CrossRef]

3. Davies, T.D.; Tranter, M.; Wigington, P.J., Jr.; Eshleman, K.N. Acidic episodes in surface waters in Europe. J. Hydrol. 1992, 132, 25-69. [CrossRef]

4. Gelfan, A. Extreme snowmelt floods: Frequency assessment and analysis of genesis on the basis of the dynamic-stochastic approach. J. Hydrol. 2010, 388, 85-99. [CrossRef]

5. Iwata, Y.; Nemoto, M.; Hasegawa, S.; Yanai, Y.; Kuwao, K.; Hirota, T. Influence of rain, air temperature, and snow cover on subsequent spring-snowmelt infiltration into thin frozen soil layer in northern Japan. J. Hydrol. 2011, 401, 165-176. [CrossRef]

6. Corriveau, J.; Chambers, P.A.; Yates, A.G.; Culp, J.M. Snowmelt and its role in the hydrologic and nutrient budgets of prairie streams. Water Sci. Technol. 2011, 64, 1590-1596. [CrossRef] [PubMed]

7. Moncur, M.C.; Ptacek, C.J.; Hayashi, M.; Blowes, D.W.; Birks, S.J. Seasonal cycling and mass-loading of dissolved metals and sulfate discharging from an abandoned mine site in northern Canada. Appl. Geochem. 2014, 41, 176-188. [CrossRef]

8. Nimick, D.A.; Gammons, C.H.; Parker, S.R. Diel biogeochemical processes and their effect on the aqueous chemistry of streams: A review. Chem. Geol. 2011, 283, 3-17. [CrossRef]

9. Ryan, R.J.; Packman, A.I. Changes in streambed sediment characteristics and solute transport in the headwaters of Valley Creek, an urbanizing watershed. J. Hydrol. 2006, 323, 74-91. [CrossRef]

10. Turcotte, B.; Morse, B.; Bergeron, N.E.; Roy, A.G. Sediment transport in ice-affected rivers. J. Hydrol. 2011, 409, 561-577. [CrossRef]

11. Huey, G.M.; Meyer, M.L. Turbidity as an Indicator of Water Quality in Diverse Watersheds of the Upper Pecos River Basin. Water 2011, 2, 273-284. [CrossRef]

12. Price, A.G.; Hendrie, L.K. Water motion in a deciduous forest during snowmelt. J. Hydrol. 1983, 64, 339-356. [CrossRef]

13. Guo, K.; Liu, X. Dynamics of meltwater quality and quantity during saline ice melting and its effects on the infiltration and desalinization of coastal saline soils. Agric. Water Manag. 2014, 139, 1-6. [CrossRef] 
14. Dittmar, T. Hydrochemical processes controlling arsenic and heavy metal contamination in the Elqui river system (Chile). Sci. Total Environ. 2004, 325, 193-207. [CrossRef] [PubMed]

15. Leiva, E.D.; Ramila, C.D.P.; Vargas, I.T.; Escauriaza, C.R.; Bonilla, C.A.; Pasten, P.A.; Pizarro, G.E. Natural attenuation process via microbial oxidation of arsenic in a high Andean watershed. Sci. Total Environ. 2014, 466-467, 490-502. [CrossRef] [PubMed]

16. Schemel, L.E.; Cox, M.H.; Runkel, R.L.; Kimball, B.A. Multiple injected and natural conservative tracers quantify mixing in a stream confluence affected by acid mine drainage near Silverton, Colorado. Hydrol. Process. 2006, 20, 2727-2743. [CrossRef]

17. Sánchez, J.; López, E.; Santofimia, E.; Reyes, J.; Martín, J. The impact of acid mine drainage on the water quality of the Odiel River (Huelva, Spain): Evolution of precipitate mineralogy and aqueous geochemistry along the Concepción-Tintillo segment. Water Air Soil Pollut. 2005, 173, 121-149. [CrossRef]

18. Sarmiento, A.M.; Nieto, J.M.; Olias, M.; Canovas, C.R. Hydrochemical characteristics and seasonal influence on the pollution by acid mine drainage in the Odiel river Basin (SW Spain). Appl. Geochem. 2009, 24, 697-714. [CrossRef]

19. McKnight, D.M.; Bencala, K.E.; Zellweger, G.W.; Aiken, G.R.; Feder, G.L.; Thorn, K.A. Sorption of dissolved organic carbon by hydrous aluminium and iron oxides occurring at the confluence of Deer Creek with the Snake River, Summit County, Colorado. Environ. Sci. Technol. 1992, 26, 1388-1396. [CrossRef]

20. Theobald, P.K., Jr.; Lakin, H.W.; Hawkins, D.B. The precipitation of aluminum, iron and manganese at the junction of Deer Creek with the Snake River in Summit County, Colorado. Geochim. Cosmochim. Acta 1963, 27, 121-132. [CrossRef]

21. Schemel, L.E.; Cox, M.H. Descriptions of the Animas River-Cement Creek Confluence and Mixing Zone near Silverton, Colorado during the Late Summers of 1996 and 1997; U.S. Open File Report. Geological Survey: Reston, VA, USA, 2005.

22. Schemel, L.E.; Kimball, B.A.; Runkel, R.L.; Cox, M.H. Formation of mixed Al-Fe colloidal sorbent and dissolved-colloidal partitioning of $\mathrm{Cu}$ and $\mathrm{Zn}$ in the Cement Creek-Animas River Confluence, Silverton, Colorado. Appl. Geochem. 2007, 22, 1467-1484. [CrossRef]

23. Adra, A.; Morin, G.; Ona-Nguema, G.; Menguy, N.; Maillot, F.; Casiot, C.; Bruneel, O.; Lebrun, S.; Juillot, F.; Brest, J. Arsenic Scavenging by Aluminum-Substituted Ferrihydrites in a Circumneutral pH River Impacted by Acid Mine Drainage. Environ. Sci. Technol. 2013, 47, 12784-12792. [CrossRef] [PubMed]

24. Arias, M.; Astray, G.; Fernandez-Calvino, D.; Garcia-Rio, L.; Mejuto, J.C.; Novoa-Munoz, J.C.; Perez-Novo, C. Sorption Behaviour of Arsenic By Iron And Aluminium-Oxides-Coated Quartz Particles. Fresenius Environ. Bull. 2008, 17, 2122-2125.

25. Bradl, H.B. Adsorption of heavy metal ions on soils and soils constituents. J. Colloid. Interface Sci. 2004, 277, 1-18. [CrossRef] [PubMed]

26. Harvey, O.R.; Rhue, R.D. Kinetics and energetics of phosphate sorption in a multi-component $\mathrm{Al}$ (III) and Fe(III) hydr(oxide) sorbent system. J. Colloid. Interface Sci. 2008, 322, 384-393. [CrossRef] [PubMed]

27. Youngran, J.; Fan, M.; Van Leeuwen, J.; Belczyk, J.F. Effect of competing solutes on arsenic(V) adsorption using iron and aluminum oxides. J. Environ. Sci. 2007, 19, 910-919. [CrossRef]

28. Stone, M.; Droppo, I.G. Distribution of lead, copper and zinc in size-fractionated river bed sediment in two agricultural catchments of southern Ontario, Canada. Environ. Pollut. 1996, 93, 353-362. [CrossRef]

29. Cowie, R.; Williams, M.; Wireman, M.; Runkel, R. Use of Natural and Applied Tracers to Guide Targeted Remediation Efforts in an Acid Mine Drainage System, Colorado Rockies, USA. Water 2014, 6, 745-777. [CrossRef]

30. Olias, M.; Nieto, J.M.; Sarmiento, A.M.; Ceron, J.C.; Canovas, C.R. Seasonal water quality variations in a river affected by acid mine drainage: The Odiel River (South West Spain). Sci. Total Environ. 2004, 333, 267-281. [CrossRef] [PubMed]

31. Cruz, C.; Calderon, J. Guia Climatica Práctica: Dirección Meterológica de Chile. 2008. Available online: http:/ / 164.77.222.61/climatologia / (accessed on 22 February 2016).

32. Ortega, H.; Diaz Munoz, G.; Campos Ortega, C. Aporte sedimentarios de los rios Lluta y San Jose en la zona costera de La Rada, Chile. Idesia 2007, 25, 37-48.

33. DGA (Dirección General de Aguas). Diagnóstico y clasificación de los cursos y cuerpos de agua según objetivos y calidad; Ministerio de Obras Publicas: Santiago, Chile, 2004. Available online: http://documentos.dga.cl/ CQA4432v1.pdf (accessed on 22 February 2016). 
34. Leiva, E.; Rios, P.; Escauriaza, C.; Bonilla, C.; Pizarro, G.; Pasten, P. Goldschmidt Abstracts 2011. Mineral. Mag. 2011, 75, 1261-1373.

35. Smakhtin, V.U. Low flow hydrology: A review. J. Hydrol. 2001, 240, 147-186. [CrossRef]

36. Nordstrom, D.; Alpers, C.; Ptacek, C.; Blowes, D. Negative $\mathrm{pH}$ and Extremely Acidic Mine Waters from Iron Mountain, California. Environ. Sci. Technol. 2000, 34, 254-258. [CrossRef]

37. Gippel, C.J. Potential of turbidity monitoring for measuring the transport of suspended solids in streams. Hydrol. Process. 1995, 9, 83-97. [CrossRef]

38. Pavanelli, D.; Bigi, A. Indirect Methods to Estimate Suspended Sediment Concentration: Reliability and Relationship of Turbidity and Settleable Solids. Biosyst. Eng. 2005, 90, 75-83. [CrossRef]

39. Guerra, P.; González, C.; Escauriaza, C.; Pizarro, G.; Pasten, P. Incomplete mixing in the fate and transport of arsenic at a river affected by acid drainage. Water Air Soil Pollut. 2016, 227, 73. [CrossRef]

40. EPA. 3051A-Microwave assisted acid digestion of sediments, sludges, soils and oils, Agency USEP, editor. Environmental Protection Agency: Washington, DC, USA, 2007. Available online: http:/ /www3.epa.gov/ epawaste/hazard/testmethods/sw846/pdfs/3051a.pdf (accessed on 22 February 2016).

41. Salas, J. Analysis and modeling of hydrologic time series. In Handbook of Hydrology, 2nd ed.; Maidment, D.R., Ed.; McGraw-Hill Professional: New York, NY, USA, 1993; pp. 1-17.

42. Nordstrom, D.K. Hydrogeochemical processes governing the origin, transport and fate of major and trace elements from mine wastes and mineralized rock to surface waters. Appl. Geochem. 2011, 26, 1777-1791. [CrossRef]

43. Sánchez-España, J.; Yusta, I.; Diez-Ercilla, M. Schwertmannite and hydrobasaluminite: A re-evaluation of their solubility and control on the iron and aluminium concentration in acidic pit lakes. Appl. Geochem. 2011, 26, 1752-1774. [CrossRef]

44. Liu, S.; Glasgow, L. Aggregate disintegration in turbulent jets. Water Air Soil Pollut. 1997, 95, $257-275$. [CrossRef]

45. Santschi, P.H.; Burd, A.D.; Gaillard, J-F.; Lazarides, A.A. Transport of Materials and Chemicals by Nanoscale Colloids and Micro- to Macro-Scale Flocs in Marine, Freshwater, and Engineered Systems. In Flocculation in Natural and Engineered Systems, 1st ed.; Droppo, I.G., Leppard, G.G., Liss, S.N., Milligan, T.G., Eds.; CRC Press: New York, NY, USA, 2005; pp. 191-210.

46. Carrero, S.; Pérez-López, R.; Fernandez-Martinez, A.; Cruz-Hernández, P.; Ayora, C.; Poulain, A. The potential role of aluminium hydroxysulphates in the removal of contaminants in acid mine drainage. Chem. Geol. 2015, 417, 414-423. [CrossRef]

47. Dzombak, D.; Morel, F. Surface Complexation Modeling: Hydrous Ferric Oxide; John Wiley: New York, NY, USA, 1990.

48. Runkel, R.; Kimball, B.; McKnight, D.; Bencala, K. Reactive solute transport in streams: A surface complexation approach for trace metal sorption. Water Resour. Res. 1999, 35, 3829-3840. [CrossRef]

49. Contreras, M.T.; Mullendorf, D.; Pasten, P.; Pizarro, G.E.; Paola, C.; Escauriaza, C. Potential accumulation of contaminated sediments in a reservoir of a high-Andean watershed: Morphodynamic connections with geochemical processes. Water Resour. Res. 2015, 51, 3181-3192. [CrossRef]

(C) 2016 by the authors; licensee MDPI, Basel, Switzerland. This article is an open access article distributed under the terms and conditions of the Creative Commons by Attribution (CC-BY) license (http://creativecommons.org/licenses/by/4.0/). 